\title{
The market reaction to debt announcements: UK evidence surrounding the global financial crisis
}

\author{
Andrew Marshalla ${ }^{a}$ Laura McCann ${ }^{\mathrm{b}}$, Patrick McColganc
}

\begin{abstract}
We examine the stock market response to announcements of public, bank and privately placed debt issuance by large UK firms surrounding the global financial crisis of 2008. Prior to the crisis, we find that stock prices respond positively to announcements of bank debt issuance only. This is restricted to the sub-sample of syndicated bank loans and this is suggestive of the certification from multiple lenders conveying a signal of creditworthiness. We find that abnormal returns on the announcement of bank loans have declined since the financial crisis, both in absolute terms and in comparison to alternative borrowing sources. Overall, our results suggest that surrounding the global financial crisis of 2008, bank loans have become less informative as a signal of the creditworthiness of borrowing firms.
\end{abstract}

JEL Classification: G14; G20

Keywords: public bonds; bilateral loans; syndicated loans; privately placed debt; event study; borrower value.

a Department of Accounting and Finance, University of Strathclyde, Glasgow, G4 0QU, UK, Tel: 44-141-548-3894, Email: a.marshall@ strath.ac.uk

b Business School, University of Aberdeen, Aberdeen, AB24 3QY, UK, Tel: 44-1224-272207, Email: 1.mccann@abdn.ac.uk

c Department of Accounting and Finance, University of Strathclyde, Glasgow, G4 0QU, UK, Tel: 44-141-548-3690, Email: patrick.mccolgan@strath.ac.uk

The authors are grateful to Douglas Cumming, Dick Davies, Paul Draper, and seminar participants at the 2015 BAFA Annual Conference (Manchester), 2015 EAA Annual Congress (Glasgow), 2016 INFINITI Conference on International Finance (Dublin), 2016 Young Finance Scholars Conference (Sussex), and the 2016 BAFA Scottish Area Group (Glasgow) conference for helpful comments on earlier versions of this work. We also thank Martin Kemmitt for helpful research assistance on this project. All errors remain our own. 


\section{Introduction}

For the largest companies in the UK, debt financing is from three primary sources: public bond markets, banks and privately placed debt markets. Yet the UK public bond market has been described as "underdeveloped" in comparison to US markets in a government report, citing evidence that the number of UK corporate bond and privately placed debt issues is comparatively lower than in other developed capital markets (Breedon, 2012). As a result, UK firms have historically placed a greater reliance on banks as their main source of borrowing. However, following the global financial crisis of 2008, there has been a widely documented decrease in access to bank finance as banks tightened their lending requirements. ${ }^{1}$ As a direct result of this contraction in bank lending, UK companies have turned more frequently to public and privately placed debt markets to meet their borrowing needs. ${ }^{2}$

In this paper we analyze the stock market response to public, bank and privately placed debt issuance for a sample of 1,537 announcements made by UK non-financial and non-utility firms listed on the FTSE-350 index of the London Stock Exchange (LSE) between 2001 and 2013. Public bonds are identified as any exchange registered bond instruments. Using the same procedure as in Marshall et al. (2016) we identify bank debt as loan facilities explicitly identified as borrowings from a bank institution and privately placed debt as issuances of debt from private investors that are not identified as banks, such as insurance firms, pension funds, and other private investor groups.

Differences in the importance of individual lending sources for UK firms, in comparison to US markets, and the documented change in debt financing patterns over our

\footnotetext{
${ }^{1}$ The Bank of England (2013) highlights that over the period January 2003 to December 2007; UK companies raised funds totalling $£ 528.3$ bn through syndicated bank loans, but only $£ 342.6$ bn was raised between January 2008 and December 2012. Adrian et al. (2012) document similar evidence for US borrowers.

${ }^{2}$ Average annual gross bond issuance by UK companies more than doubled from $£ 20.6 \mathrm{bn}$ to $£ 45.2 \mathrm{bn}$ between 2003 and 2007 (Bank of England, 2015). Similarly, issuance of privately placed debt by UK companies in US private placement markets almost doubled from £53.8bn to £91.6bn (International Financial Law Review, 2013).
} 
sample period motivates us to examine how the stock market responds to announcements of borrowing from the different sources of debt finance available to UK companies, and to examine how the stock price response has changed surrounding the 2008 financial crisis.

A number of theoretical models argue that private debt has advantages over public debt. For example, banks can provide additional financial services to their clients and also have superior monitoring, screening, insurance and certification functions (Nakamura, 1993). Signalling models emphasize that if banks are privy to inside information through bank lending activities, they would not offer or renew a loan to a borrower if they discover unfavourable information on the firm (Bernanke, 1983; Fama, 1985). This superior ex-ante certification and ex-post monitoring of borrower companies by lending banks should engender a more positive stock price response to debt issuance announcements from this source. Consistent with this, the stock price response to bank debt issuance has been found to be generally positive (Billett et al., 1995; James, 1987), close to zero for issues of public debt (Hadlock and James, 2002; Mikkelson and Partch, 1986), and is mixed for privately placed debt issuance (Chandra and Nayar, 2008; James, 1987).

The more positive response to announcements of bank debt by corporate borrowers has often been attributed to these "special" characteristics of bank lending. However, given changes in borrowing trends for UK firms surrounding the crisis: restricted access to bank credit, increased importance for syndicated over bilateral bank loans, and the growing importance of public and privately placed debt, we propose that the stock price response to corporate borrowing announcements has changed surrounding the crisis. On the one hand, the monitoring benefits of bank debt may have increased during the crisis given restricted access to borrowing, leading to a more positive stock price response. Alternatively, if bank lending is granted on onerous terms during the crisis, the high cost of obtaining finance will lead to a lower stock price response to loan announcements. 
Consistent with theories of relationship lending, for our full sample we find significant and positive announcement returns to bank loans, and no evidence of abnormal returns surrounding public and privately placed debt issuance. To gain further insight, we split our bank loan sample based on the number of lenders, and we find the positive market response to bank loans is driven by syndicated loans rather than the more traditional bilateral loans. This finding is suggestive of the certification from multiple lenders conveying a signal of the creditworthiness of the borrowing company.

Further, we find that positive announcement returns to bank loans are driven by issues made prior to the global financial crisis. Stock price returns to bank loan announcements are significantly lower from 2008 onwards. This less favourable market reaction can be explained by credibility problems in the banking system post financial crisis and the clear expost evidence that bank lending decisions made in the period prior to the crisis were poor on average. In general, our finding highlights that bank loans may no longer generate their expected creditworthiness signalling advantages for borrowing firms, often labelled as making bank loans "special" in the literature on corporate borrowing source.

We contribute to literature on the market response to debt issuance announcements in two main ways. First, as our sample period encompasses the global financial crisis of 2008 we can examine how the market views the announcement of debt offerings from public, bank and privately placed sources during a period where firms suffered restricted access to bank credit. Our findings highlight that the positive effects of accessing bank loans for borrowing firms vary with market conditions, availability of credit and the potential monitoring strength of the lending institution.

Second, we extend prior US literature on the market response to debt source announcements to the UK market. We argue that a UK single country study is interesting for several reasons. As described previously, bank loans to UK companies are more important 
than bank loans to US companies as a source of debt finance. Moreover, the lack of developed public bond markets make syndicated loans in the UK an important source of borrowing. Bank of England reports $(2009,2012)$ show an increase in provision of lending through syndicated bank loans in recent years and to the detriment of traditional bilateral loans. Also, the UK private placement market is an underdeveloped market in contrast to the established private placement market in the US, which has been a historically important source of debt finance for US companies (Breedon, 2012; Slaughter and May, 2014). To date, Armitage's (1995) analysis of syndicated loans has been, to our knowledge, the only study to provide a systematic analysis of the stock market response to debt issuance classified by borrowing source in a UK setting.

The remainder of this paper is structured as follows. Section 2 summarizes prior literature on the market response to debt issuance and presents our hypotheses. Section 3 outlines our sample construction and empirical testing. We present our results in Section 4 and we conclude in Section 5.

\section{Literature review and hypotheses development}

\subsection{Market reaction to debt issues}

Theoretical research illustrates that the monitoring and screening services provided by banks help to reduce information asymmetries between borrowers and lenders, endorsing firm quality, and signalling creditworthiness to outside investors. Diamond (1984) and Gomes and Phillips (2012) argue that, ex ante, banks are better positioned to make informed decisions regarding a borrower's credit quality in comparison to other private and public lenders. Banks acquire proprietary information in the process of repeat lending and provision of other banking activities, such as the firm's deposit history, that is unavailable to outside lenders. Having built up expertise in monitoring firms that have received loans, banks are 
also better positioned than other lenders to continue to monitor the borrowing firm ex post. Signalling models emphasize that if banks are superior monitors, and have access to proprietary information, they will only lend to companies considered creditworthy (Bernanke, 1983; Fama, 1985).

Based on these theoretical arguments, we expect that announcements of bank debt have a positive impact on the borrowing firm's market value. Empirical evidence for US companies generally confirms this. Billett et al. (1995), James (1987), and Lee and Sharpe (2009) find a positive market reaction bank debt issuance. Supporting the US evidence, Fungáčová et al. (2015) find a positive market response to bank loans for European firms. Armitage (1995) examines syndicated loans for UK firms and finds no significant market response to loan announcements. Bailey et al. (2011) and Huang et al. (2012) find a negative market response in China, which they link to potential for expropriation of borrowed funds by large state investors. ${ }^{3}$

Studies have almost uniformly reported little or no response to issues of public debt issuance (Hadlock and James, 2002; James, 1987; Mikkelson and Partch, 1986). James (1987) finds that the market responds negatively to privately placed debt announcements, but Chandra and Nayar (2008) and Preece and Mullineaux (1994) find a positive market response for privately placed debt. These results collectively show that the market reaction to bank loans is comparatively different to other sources of external debt financing. Therefore, in Hypothesis 1 we consider whether this result holds for a UK sample of debt issues:

H1. The stock market response to bank loan announcements by UK companies is greater than for other sources of corporate debt.

\footnotetext{
${ }^{3}$ A number of studies have also reported that the positive market response is restricted only to specific subsections of empirical data sets. Fery et al. (2003) find that the market responds positively only to bank loan announcements published in the financial press. Maskara and Mullineaux (2011) illustrate that the positive response to bank loan announcements is restricted to only the smallest firms in their sample.
} 


\subsection{Syndicated versus bilateral bank loans}

In addition to the market response to announcements of different debt sources, we also examine the market response to both syndicated and bilateral bank debt. Bilateral and syndicated loans differ in at least two crucial ways that could drive a different market response to their announcement.

The first difference concerns the parties involved in the loan: a bilateral loan is an agreement between an individual borrower and an individual lender, whereas a syndicated loan involves a number of lenders and can be viewed as an intermediate borrowing source between traditional bilateral loans and public debt markets (Dennis and Mullineaux, 2000; Marshall et al., 2016; Sufi, 2007). The potential free rider problems created in a lending syndicate can restrict the monitoring benefits of bank debt to bilateral loans only. If lenders in syndicated loans have weaker incentives to monitor borrowing firms, the stock price reaction to syndicated loans will be lower in comparison to bilateral loans because lending syndicates are closer in structure to arms-length public debt contracts.

The second difference is the overall value of the loan: given that there is only one lender in a bilateral lending agreement, bilateral loans tend to be for smaller amounts than syndicated loans. Syndication allows for diversification of risk within the lending syndicate and higher loan amounts overall. If loan size is correlated with the incentive to monitor, we argue that the market response will be higher for syndicated loans.

Based on these differing predictions, in Hypothesis 2 we examine the market reaction to syndicated and bilateral bank loan announcements separately:

H2. There is a difference in the stock market response to bilateral bank loans in comparison to syndicated bank loans. 


\subsection{The impact of the 2008 global financial crisis}

In Hypothesis 3, we examine the stock price response to debt issuance announcements surrounding the global financial crisis. The crisis provides us with an opportunity to examine whether the restricted access to bank credit during this period affected the announcement returns to different debt sources in the UK, particularly as firms have moved away from their previous strong reliance on bank financing. We specifically examine if the positive signal from bank debt financing remains during the financial crisis period, relative to the pre-crisis period and other borrowing sources during the crisis.

In the years prior to the financial crisis, it was widely reported that banks operated with less stringent screening and monitoring standards due to a number of factors, including the increasing availability of private sector debt and the amount of competition in the banking system (Adrian et al., 2012; Carbo-Valverde et al., 2011). However, the onset of the financial crisis incentivised banks to adopt more stringent screening and monitoring of borrowers as banks could no longer sell-on so called crisis loans in the secondary market due to market illiquidity.

Consistent with banks lowering their monitoring efforts prior to the crisis (Purnanandam, 2011) and then intensifying their monitoring efforts during the crisis period (De Haas and Van Horen, 2010), Li and Ongena (2015) find positive returns to bank loan announcements between September 2007 and December 2009, but no significant market response to announcements between January 2005 and August 2007. This suggests that when firms have been able to secure bank funding during this period of restricted access, the market views the announcement as an endorsement of firm quality.

Whether these results hold for the UK is an empirical issue we examine in the current paper. The UK economy suffered more difficulties than most other economies during the 
financial crisis given the size of the banking sector in comparison to the overall economy. As with other banking systems, there has been clear evidence of poor prior lending decisions. We propose that the restricted credit availability and potentially onerous terms for credit granted post crisis can reduce or eliminate the positive market signal from bank lending post crisis. There is some empirical support for this argument in non-US markets. Fungáčová et al. (2015) find that the market response to European loan announcements made after May 2010 is lower than those announcements made prior to the Eurozone crisis and Godlewski (2014) reports a negative market response to syndicated loans issued by French companies during the crisis period. Therefore, in our final hypothesis we consider if the financial crisis has had an impact on abnormal returns surrounding announcements of bank debt:

H3. The stock price response to bank loan announcements by UK issuing companies is lower during the global financial crisis.

\section{Data and research method}

\subsection{UK debt announcement data}

Our sample of announcements of straight corporate debt announcements is for all non-financial and non-utility firms in the FTSE-350 index of the London Stock Exchange (LSE) from 2001 to 2013. For these 401 firms we hand collect announcements of public, bank, and privately placed issues through Nexis UK (covering national and regional newspapers and Regulatory News Service (RNS) announcements made by LSE firms) using the keywords on debt announcement used in Hadlock and James (2002). ${ }^{4}$ Private debt is only

\footnotetext{
${ }^{4}$ Also we search on: "bond," "bond issue," "debt notes," "line of credit," "loan facility," "working capital facility," "private placement," and "overdraft."
} 
classified as bank debt when the lender is clearly acknowledged as a bank (Johnson, 1997). If the debt is not clearly identified as from banks it is classified as privately placed debt. ${ }^{5}$

From our original search we have a sample of 1,682 announcements of debt issues by 337 different firms. We apply a number of filters that results in a final sample of 1,537 debt announcements consisting of 967 issues of bank debt (767 syndicated loans and 200 bilateral loans), 370 issues of public debt, and 200 issues of privately placed debt. ${ }^{6}$

As our sample is obtained from the newspaper and RNS coverage collected by Nexis UK, one concern is whether this actually covers all UK debt announcements. For example, Maskara and Mullineaux (2011) state that approximately three quarters of US bank loans are not publicised in the media. LSE firms are required to disclose information on material capital changes and these are reported in the RNS. However, what is considered material is subjective and if managers do not view the information to be price sensitive they will not disclose issues of private bank debt or other privately placed debt. Therefore to check we have as full a population of loans as possible for our sample firms, we cross-check our sample with a number of relevant financial databases.

All UK public bond issues are disclosed to the market as issuing firms must apply to the London Stock Exchange and the UK Listing Authority. Therefore we check our sample of 370 announced public bonds with information from Thomson ONE and DataStream. We find no new public bond announcements through these databases. We check our 943 bank loan announcements with the DealScan database. We find an additional 24 unannounced bank loan announcements from DealScan (97\% similarity in the two samples) and therefore we have a final sample of 967 bank loans. ${ }^{7}$ Finally, we check our sample of 196 announced non-

\footnotetext{
${ }^{5}$ This approach may under-report the importance of bank debt and overstate the importance of privately placed debt. However, more than $75 \%$ of private debt announcements are classified as bank debt, suggesting that this categorization has not created a sizeable bias against identification of bank loans.

${ }^{6} 85$ announcements were removed as the debt announcement coincided with another major firm announcement and a further 60 announcements were eliminated due to missing share price data.

${ }^{7}$ Our initial Nexis UK sample contained only one loan that was not included on the DealScan database.
} 
bank private loans against the Private Placement Letter database. There is an overlap of $98 \%$ for our sample and we add only 4 unannounced non-bank private loans to our sample, resulting in a final sample of 200.

We are also reasonably confident that our sample of private bank and privately placed debt announcements comprises the population of loans, despite there being no legal requirement for companies to publicly disclose private borrowing agreements, for our sample for two reasons. First, our sample is comprised of the largest 350 companies on the LSE, information about these companies is scrutinised by analysts and reported in more detail than for smaller UK firms. Therefore, debt issues made by these companies are more likely to be covered in the financial press and picked up by Nexus UK coverage of newspapers, RNS announcements by firms, and by commercial data providers including DealScan. Second, in addition to the firms themselves disclosing price sensitive information, it is in the interests of lenders to disclose or advertise loans they have made to commercial data providers, so that the loans are represented in each lender's league table rank.

\subsection{Control variables}

To control for confounding factors that may impact the market response to debt issuance announcements we also control for loan characteristics, lender characteristics, and firm characteristics at the financial year-end prior to the announcement. We discuss these variables here and we summarize definitions and data sources in Table 1.

[Insert Table 1 about here]

\subsubsection{Loan characteristics}


Loan size. Shepherd et al. (2007) argue that lender monitoring incentives increase with loan size and as such lenders are likely to have stricter pre-loan diligence on larger loans than smaller loans. Loan size is the value of the issued loan deflated to the year 2000 using consumer price inflation.

Loan maturity. Maturity could impact on the market reaction to debt issues. Ho and Singer (1982) state that that long-term debt may be riskier than short-term debt because there is a greater likelihood of long term debt not being repaid in full. Moreover, Flannery (1986) argues that the maturity of the issued debt provides an indication of managerial opinion on firm value and earnings prospects. Loan maturity is a count of the number of years to maturity.

Renewal status. Lummer and McConnell (1989) examine the market response to new loan announcements and loan renewals and find a positive market response to loan renewals only. This suggests that banks only gain access to inside information through a repeated lending relationship. Renewal status is measured as a dummy variable set equal to one for loans where the announcement states that the loan is a renewal, revision, renegotiation or extension of an existing credit agreement, and zero otherwise.

Use of proceeds. The use of proceeds can impact the market reaction to security issues (Slovin et al., 2000). Therefore we use a dummy variable, Refinance, set equal to one for loans where the announcement notes that the stated use of proceeds is to refinance existing debt. Acquisition is a dummy variable set equal to one for loans where the announcement notes that the stated use of proceeds is to finance acquisitions. Other is a dummy variable set equal to one for loans where the announcement notes an intended use of proceeds other than acquisition or debt refinancing. Unclassified is a dummy variable set equal to one for loans where the announcement does not provide a stated use of proceeds. 
Use of proceeds is not mutually exclusive and firms do state more than one reason for their debt issuance in some cases.

\subsubsection{Firm characteristics}

Firm size. Consistent with Fama's (1985) notion that larger firms already operate under the scrutiny of numerous external monitors and/or bank's being able to extract more information from smaller borrowers, Slovin et al. (1992) find no significant market response to loan announcements made by large companies, but a positive response to announcements made by smaller companies. This result is suggestive of loan announcements for smaller companies conveying more information than larger companies as they market knows less about the former. We measure Firm size as book value of total assets (£billions) deflated to the year 2000 using consumer price inflation.

Asset tangibility. The market reaction to a debt issue could be influenced by the level of tangible assets the firm has to offer as security on the loan (Denis and Mihov, 2003). We measure Asset tangibility as the ratio of plant, property, and equipment to total assets.

Firm age. We expect the age of the borrower firm can impact the market reaction to debt issuance under reputation based theories of access to credit (Diamond, 1991). We include Firm age as our measure of a borrower's reputation in credit markets. Age is measured from the date of incorporation.

Leverage. The amount of existing debt in the firm's capital structure could impact on the market reaction to new debt issues, especially in relation to bank debt. Hoshi et al. (1993) argue that there should be a positive relation between the use of bank debt and leverage because firms with higher leverage require the monitoring that banks provide as they are more likely to engage in risk shifting strategies and have less to lose from high risk investments that do not pay off. Easterwood and Kadapakkam (1991) argue that firms will 
employ more private debt if they have greater leverage since the expected costs of financial distress are lower when debt can be more easily reorganised. Leverage is defined as book value of total debt divided by book value of total assets.

Stock price performance. The market reaction to debt issues could also depend on the prior performance of the firm. Hadlock and James (2002) find that bank debt issuers are likely to have underperformed firms issuing public debt and equity. They attribute the positive stock price response to bank loan announcements as evidence of undervaluation. We measure Stock price performance as the daily buy-and-hold return over the firm's accounting year minus the return on the FTSE 350 index over the same time period.

\subsubsection{Lender reputation characteristics}

UK lender. Agarwal and Hauswald (2007) find that local banks have an advantage over more remote competitors in the collection of soft proprietary information for monitoring. Therefore, we examine lender nationality to investigate whether UK banks are better informed than their foreign counterparts. UK lender is a dummy variable set equal to one for loans where the lending bank's headquarters are located in the UK, and zero otherwise. For syndicated loans we focus on the headquarter location of the lead arranger.

Lender bailout. Prior to the financial crisis there is evidence that banks were not adopting high standards of monitoring and made bad lending decisions (Carbo-Valverde et al. 2011; Purnanandam, 2011). Following the crisis, the UK government provided a bank rescue package to the value of $£ 500 \mathrm{bn}$ to support struggling banks and to reassure the stock market that UK banks would survive. To examine the reputation of the lending bank we define Lender bailout as a dummy variable equal to one for loans where the lending bank received a government bailout during the financial crisis, and zero otherwise. 
Lender credit rating. Billet et al. (1995) find that the stock market response to bank loan announcements is increasing with a firm's bond rating. For example, they find a positive market response to loans from lenders rated Aaa by Moody's but no evidence of a market response to lenders rated below Baa. Lender credit rating is a dummy variable set equal to one for loans where the lending bank had a S\&P credit rating of AA or above at the time of the loan agreement, and zero otherwise. ${ }^{8}$

\subsection{Descriptive statistics}

Table 2 presents the distribution of the sample of announcements of debt issuance by type. The apparent limited use of privately placed debt suggests that companies prefer to borrow from the main public bond market and bank debt sources, and limit their issues of privately placed debt to specific circumstances (Denis and Mihov, 2003).

[Insert Table 2 about here]

Table 2 also presents the annual distribution of loan announcements in the sample. Issues of public and privately placed debt are less frequent as the economy enters the financial crisis. In contrast, we find that issues of bilateral bank debt increase towards the end of our sample period. This suggests that for our sample of large firms, banking relationships became more important during the period of credit constraints in the wider economy. The widely documented decline in bank lending following the financial crisis appears to be driven by a reduction in the availability of syndicated, rather than bilateral, bank loans for our sample firms.

\footnotetext{
${ }^{8}$ Our results are unchanged if we split high reputation lenders as those with a credit rating of A and above, following Billet et al. (1995). However, there are only 12 loans in our sample made by lenders with less than an A rating from $S \& P$.
} 
We present summary statistics for loan and firm characteristics for each borrowing source in Table 3. Diamond's (1991) reputation building theory can explain variations in firm characteristics across different borrowing sources. Issuers of both syndicated and bilateral bank debt are typically younger and smaller than issuers of public debt. The average firm that issues bank debt is incorporated for 42.05 years with book assets of $£ 3.91$ billion, compared to 49.25 years and $£ 13.14$ billion for public debt issuers. Privately placed debt issuers are older, but smaller, than firms that issue bank debt.

Companies using privately placed debt have the lowest levels of tangible assets to offer as collateral against their loans, and are likely forced to borrow in private debt markets because they have likely been screened out of borrowing in the public debt market (Denis and Mihov, 2003).

[Insert Table 3 about here]

The average bank loan is $£ 397$ million, which is almost one and a half times larger than the average public bond issue ( $£ 278$ million) and over four times greater than the average issue of privately placed debt (£97 million). Confirming the importance of separately examining the market response to bilateral and syndicated loans, the average syndicated loan ( $£ 447$ million) is considerably larger than the average bilateral loan ( 212 million). This further highlights the importance of the UK context to our study, where syndicated loans have been shown to act as a hybrid step between bank lending and public bond issues (Marshall et al., 2016). If lender certification and monitoring is a function of the amount borrowed, we expect a more positive response to syndicated loan announcements in comparison to bilateral loans. Syndicated borrowers have fewer assets than public bond issuers but make use of multiple lenders to raise larger amounts of debt. 
Consistent with prior US studies (see Arena, 2011; Denis and Mihov, 2003), the average bond has a maturity of 12.58 years, which is three times the maturity of a typical bank loan. Privately placed debt is issued for average maturities between these two other sources, with a mean of 8.75 years. Syndicated and bilateral bank loans have similar maturities, with an average of four years, suggesting that maturity is unlikely to be a factor to explain differences in the stock price response to these announcements (see Preece and Mullineaux, 1996). ${ }^{9}$

\subsection{Event study}

We use the standard market model to estimate abnormal returns with an estimation period of 170 days (-200 to -31 days) relative to announcements of debt issuance. The market model is defined as:

$$
E\left(R_{i t}\right)=\alpha_{i}+\beta_{i} E\left(R_{m t}\right)
$$

where, $\alpha_{i}$ and $\beta_{i}$ are OLS estimates of firm i's market model parameters, and $R_{m t}$, the benchmark index, is the return on the FTSE-350 market index in period $t$.

The announcement date, day 0 , is the date of the first public announcement of the borrowing agreement or debt offering in the press.

The daily abnormal return is defined as:

$$
A R_{i t}=R_{i t}-\alpha_{i}-\beta_{i} R_{m t}
$$

\footnotetext{
${ }^{9}$ To check that the presence of outliers or skewness in the data does not drive our results we winsorize the top and bottom $10 \%$ of all observations for our control variables and replace the values below (above) the $10 \%$ quantile ( $90 \%$ quantile) by the $10 \%(90 \%)$ quantile values of the variable's distribution and re-run our OLS regressions. Our empirical results are robust to the exclusion of outliers.
} 
where, $R_{i t}$ is the return on security i over period t, $\alpha_{i}$ and $\beta_{i}$ are OLS estimates of firm i's market model parameters, and $R_{m t}$ is the return on the FTSE 350 market index in period t.

We calculate cumulative abnormal returns (CARs) for a three-day window $[-1,+1]$ surrounding the announcement to capture any information leakage or delay in response to the announcement:

$$
C A R_{i T}=\sum_{t=1}^{T} A R_{i t}
$$

Finally we assess the significance of CARs using standard Student's t-tests calculated as:

$$
t_{C A R_{\tau, T}}=\frac{C A R_{\tau, T}}{\sigma_{t} / \sqrt{N}}
$$

where, $\mathrm{N}$ is the number of observations over the period which the CAR is calculated, and $\sigma_{t}$ is the standard deviation of abnormal returns over the estimation period.

\section{Empirical analysis}

\subsection{Market reaction to public, bank, and privately placed loan announcements}

The univariate analysis of loan announcement abnormal returns is presented in Panel A of Table 4. Consistent with the US studies including Johnson (1995) and Mikkelson and Partch (1986), we find no evidence of either a statistically or economically significant response to announcements of public debt. Similarly, the results indicate no significant market response to privately placed debt announcements. This is in contrast with James (1987), who finds a small negative response. 
Consistent with the theory that bank loans can signal favourable information to the market, we find positive CARs of $0.56 \%$ surrounding bank loan announcements (significant at the 5\% level). This result is comparable to the US studies of Billett et al. (1995) and James (1987), and the European analysis of Fungáčová et al. (2015). The positive stock market response for bank loans and insignificant market response for both public debt and privately placed debt provides support for our Hypothesis 1.

This is consistent with Fama's (1985) view of banks being able to obtain otherwise private information on borrower creditworthiness that can be used to monitor and improve corporate decision making at borrowing firms. Our finding provides preliminary evidence that banks are relationship lenders who are able to monitor borrowing firms. This is reflected in a positive stock price response to bank loans, both in absolute terms and with reference to alternative borrowing sources.

[Insert Table 4 about here]

Given the notable differences in firm and loan characteristics between syndicated and bilateral bank loans in Table 3, we separately examine the stock market response to syndicated and bilateral loans to test our Hypothesis 2. We find that the positive market response to bank loans is driven by the sample of syndicated loans, where the average CAR is $0.57 \%$ (significant at the 5\% level). CARs are indistinguishable from zero for the sample of bilateral bank loan announcements. This provides initial support for Hypothesis 2 and is consistent with Focarelli et al. (2008), although contrasts with Armitage's (1995) earlier UK results. We argue that the positive market response to syndicated loans reflects the benefits of lender monitoring by the syndicate lead arranger (Dennis and Mullineaux, 2000). The result 
also reflects the size of syndicated loans and the signal of creditworthiness provided by the larger lending commitment.

In Panel B of Table 4, we test for differences in mean CARs for bank and syndicated bank debt against public bonds and privately placed debt. CARs to announcements of privately placed loans are significantly lower relative to bank debt. This result holds irrespective of whether we examine all bank loans, or separately compare against both syndicated and bilateral loans. This is consistent with James (1987) and provides further support for Hypothesis 1. However, we find no significant difference between CARs for bilateral and syndicated loans, which fails to support Hypothesis 2.

\subsection{Impact of the global financial crisis on the market reaction to public, bank, and privately} placed debt announcements

To examine Hypothesis 3 on changes in abnormal returns to debt announcements surrounding the financial crisis, we follow Curcio et al. (2017) and define the start of the crisis as January $1^{\text {st }}$, 2008. Curcio et al. (2017) state that the financial crisis started in 2007 in the US and expanded into Europe in 2008. As our sample comprises loans issued by UK firms, from predominately UK or European headquartered banks, we follow this approach. Debt issues announced prior to January 2008 are defined as pre-crisis period loans. Debt issues announced after January $1^{\text {st }}, 2008$ are defined as crisis period loans.

We provide preliminary evidence on the changing borrowing source for our sample firms in Figure 1, which reports year-end balance sheet debt outstanding for our sample firms across each of the three main debt sources that we consider. The figure clearly illustrates that UK firms' use of bank debt has declined since the crisis. At the same time, the relative importance of both public and privately placed debt as a source of corporate borrowing has 
increased. For those bank loans made since the crisis, there has been an increase in the relative importance of syndicated over bilateral bank lending (Bank of England, 2009, 2012).

[Insert Figure 1 about here]

Table 5 presents summary statistics for the samples of public, bank (syndicated and bilateral), and privately placed debt issues in the pre-crisis and crisis periods. Panel A reports loan characteristics between the two periods. We find that median loan size significantly increased and average loan size relative to total assets declined for public bonds during the crisis, but otherwise there is no difference in the size of loans or the proportion of new loans and loan renewals in the pre-crisis and crisis periods for any debt type.

Average loan maturity is significantly lower in the crisis period for public bonds, syndicated loans and privately placed debt. During the crisis period, lenders appear to have increased their monitoring of borrowing firms by requiring that loans be rolled over with greater frequency (Barclay and Smith, 1995). Moreover, we find that the stated use of borrowed funds differs surrounding the crisis. Firms are less likely to borrow in order to refinance debt or for acquisition purposes in public bond markets or using syndicated loans during the crisis, and there is a notable increase in the relative popularity of other reasons being given as a rationale for debt issuance.

[Insert Table 5 about here]

Panel B reports differences in firm characteristics for borrowing firms over both periods. In the crisis period, the median issuer of public debt is larger than in the pre-crisis period and the median issuer of bank debt is smaller. Issuers of public and privately placed 
debt have lower fixed asset ratios during the crisis. We interpret this is showing that large firms with weaker collateral made greater use of public markets when banks tightened lending criteria during the global financial crisis.

We present announcement returns surrounding the crisis in Table 6. Similar to Table 4, we find no evidence of a significant market response to issues of public bonds or privately placed debt in either the pre-crisis or crisis period. However, we do find a difference in the response to syndicated bank loan announcements. In the pre-crisis period, we find a positive market response of $1.04 \%$ to syndicated bank loans (significant at the $1 \%$ level), but in the crisis period, abnormal returns are indistinguishable from zero. We find no evidence of a significant stock price response to bilateral bank loans during either period.

We formally examine the differences in CARs between the two periods in Panel C of Table 6 to test whether the market responded differently to debt issues surrounding the financial crisis. We find a significant decline in the market response to syndicated bank loans in the crisis period to the magnitude of $-1.10 \%$ (significant at the $5 \%$ level), but there is no evidence of the market responding differently to public or privately placed debt during the crisis period. This supports Hypothesis 3 and suggests that, in contrast to other borrowing sources, the financial crisis has had a significant and negative impact on stock market returns surrounding bank loan announcements. Our findings indicate that the previous positive signal provided by the monitoring mechanism of UK banks is less convincing to investors in the crisis period.

[Insert Table 6 about here]

Our findings that bank loan announcement returns are lower during the crisis is consistent with Godlewski (2014), who reports a lower stock market response in his sample 
of syndicated bank loans to French borrowing firms during the financial crisis. However, we do not believe that this result is necessarily suggestive of the benefits of bank loan financing having weakened over time, as proposed by Fields et al. (2006). Given the poor economic environment, it is possible that the lack of a positive market response to bank loan announcements during the crisis period reflects market awareness that borrowing firms have to meet onerous conditions, including high interest rates and restrictive covenants, to access bank lending during this period.

Before proceeding, we examine the sensitivity of our findings to the definition of the global financial crisis period and split our crisis period into two shorter periods: 2008-2009 (which we term as during-crisis period loans) and 2010-2013 (which we term as post-crisis period loans). We differentiate between these two periods for two reasons. First, it can be argued that the economic conditions surrounding loans announced between 2008-2009 and 2010-2013 differ, and that the latter years reflect a post-crisis time period. Between Q2 2008 and Q2 2009 the UK was in its deepest recession since WWII. However, in Q3 2009 the UK exited a formal recession and the London Stock Exchange staged a recovery from mid-2009 onwards.

Second, as illustrated in Table 2, the number of (syndicated) bank loans announced in 2010 is significantly higher than in 2008 and 2009. This trend in our sample is supported by the Bank of England Credit Conditions Survey (2014) which suggests that after late 2009 there was some relaxation in the tightness of credit conditions, particularly with reference to a marked improvement in credit spreads on loans to large firms making it more attractive and easier for these firms to access debt financing from banks than in the 2008-2009 during-crisis period sample period. Therefore, in Panels D to F of Table 6 we examine the market response to debt issues separated in these two shorter periods. We find no difference in the market 
reaction for any of our debt types between these two sub-periods. Therefore, we proceed with our original pre-crisis and crisis period analysis. ${ }^{10}$

\subsection{Why is the information content of syndicated bank loans smaller during the financial} crisis?

Caprio (2005) argues that this distrust in banks is one of the greatest and unmeasured costs of any financial crisis. Following the global financial crisis, it is reasonable to surmise that there has been a widespread distrust of banks. An implication of this is that the reputation of the lending bank may be an important factor during the financial crisis period. In this section we extend our analysis of Hypothesis 3 to examine one potential channel through which the signalling benefits of bank debt change surrounding the financial crisis. We propose that lender reputation impacts upon the market response to issues of bank debt and that lender reputation has changed surrounding the financial crisis. We present the results of this testing in Table 7.

We first examine if the location of the lender impacts upon the market response. Syndicated bank loans from UK lenders generate positive CARs of $0.69 \%$ (significant at the $5 \%$ level). However, when the lending bank's headquarters are located outside of the UK the market response is indistinguishable from zero. This suggests that for UK companies, banks headquartered in the UK are viewed as being better informed due to their close proximity to the borrowing company, which provides them with access to enhanced soft information on borrowing companies. This is consistent with Hauswald and Marquez (2005), who argue that there is an inverse relation between the distance between the lending bank and the borrowing company and the quality of the lending bank's monitoring, screening and information gathering activities. Degryse and Ongena (2005) also find that banks charge engage in

\footnotetext{
${ }^{10}$ In further testing, we split our sample by intended use of proceeds and renewal status of the loan. We find no significant evidence that the market reaction to loan announcements conditioned on these criteria has varied surrounding the financial crisis.
} 
"spatial price discrimination" and increase loan rates with the distance between the borrowing company and the lending bank.

[Insert Table 7 about here]

Next, we examine whether or not the market responds differently to loans where the lender received a government bailout during the crisis. Where the lending bank did not receive a bailout, we find a positive market response of $1.04 \%$ (significant at the $5 \%$ level). However, loans made by banks which did receive a government bailout generated no significant market response. This result suggests that even prior to the onset of the financial crisis, the market viewed these lending banks as potentially having less stringent credit and monitoring standards, and therefore receiving a loan from these banks was less of a positive signal of borrower creditworthiness.

Finally, we investigate the whether the credit rating of the lending back has an impact on how the market responds to bank loan announcements. When the lender has an S\&P credit rating of AA or above we find a positive market response of $0.89 \%$ for syndicated loans (significant at the 5\% level), but we find no evidence of a significant market response to loans provided by lenders with a credit rating below AA. This is consistent with Billett et al. (1995).

Overall, the results in this section highlight an important mechanism through which the positive signal of borrower creditworthiness from bank lending has reduced surrounding the financial crisis. Our results provide preliminary evidence that the reputation of the lending bank is an important determinant on how the market responds to syndicated loan announcements. We examine this issue in more detail in the next section after controlling for loan and firm characteristics. 


\subsection{Multivariate analysis of debt issuance announcements surrounding the financial crisis}

The univariate results presented in Tables 6 and 7 show a decline in the market response to syndicated bank loans during the financial crisis, but no evidence of the market responding differently to public and privately placed debt. The univariate results assume that the market's response to debt announcements is influenced by only the type of lender and by economic conditions surrounding the announcement. Prior studies have also noted that borrower and loan characteristics can influence the market reaction to debt issuance announcements. Therefore, we estimate OLS regressions of announcement CARs against our key financial crisis variable (Crisis) and control for borrowing firm and loan characteristics. We present regressions of event study CARs for each borrowing source in Table 8 .

Consistent with our previous findings, Models 1 and 5 show no change in the stock price response to public bond and privately placed debt announcements respectively surrounding the global financial crisis. The insignificant F-statistic and individual regression coefficients highlights that our explanatory variables are unable to explain event study CARs surrounding loan announcements from these borrowing sources.

[Insert Table 8 about here]

We confirm in Model 2 that abnormal returns are significantly lower for bank loan announcements made during the global financial crisis, after controlling for firm characteristics known to affect the borrowing source decision (Denis and Mihov, 2003; Johnson, 1997). The coefficient on our crisis dummy highlights that returns are $0.99 \%$ lower during the crisis (significant at the 5\% level). We separately examine syndicated and bilateral loans in Models 3 and 4 respectively. In Model 3 abnormal returns surrounding syndicated 
loan announcements are $1.40 \%$ lower during the crisis (significant at the $1 \%$ level). We find no significant change in the stock price response to bilateral loans surrounding the crisis. For control variables, we find a negative relation between firm size and abnormal returns for the sample of syndicated loan announcements.

Our results provide preliminary evidence that the positive signal from bank loans has reduced significantly during the financial crisis. To rule out alternative explanations related to changing loan characteristics surrounding the crisis and to examine the potential channel through which the positive signal from bank lending is reduced, we focus only on syndicated loans and add additional control variables for loan and lender characteristics in Table 9. In each case, the crisis coefficient remains significant and negative at the 5\% level or better. The coefficient ranges from $-1.06 \%$ to $-1.51 \%$, confirming the robustness of our finding that stock prices of borrowing firms respond less positively to the announcement of syndicated bank loans during the financial crisis. This provides additional support for our Hypothesis 3, the general trend documented in Fields et al. (2006), and the financial crisis results of Godlewski (2014) for syndicated loan announcements by French borrowing firms. ${ }^{11}$

[Insert Table 9 about here]

We extend the OLS regressions in Table 9 to include interaction effects between lender characteristics and the crisis period in Table 10. We find no evidence in Models 1 or 3 that the headquarter location or credit rating of the lender bank interacts with the financial crisis to affect the stock market response to syndicated loan announcements.

[Insert Table 10 about here]

11 In further testing, we examine interaction effects between the Crisis dummy and both firm and loan characteristics. We find no evidence of a significant interaction effect to suggest that specific firm or loan characteristics drive the changing stock price response to syndicated loan announcements surrounding the crisis. 
In Model 2, the co-efficient for both the crisis variable and the lender bailout dummy are significant and negative, and the interaction between the variables is significantly positive (all significant at the $1 \%$ level). We interpret this as showing that the market viewed loans from banks which had been bailed out during the global financial crisis less positively prior to the crisis, and that generally loans made during the crisis are viewed less positively by stock market investors. Under the theory that bank loans signal borrower creditworthiness, the positive interaction term shows an expected improvement in lender monitoring during the crisis for those banks receiving government bailouts. The lower stock price response to syndicated loans during the crisis period is less for loans provided by bailed out banks. This also supports the view that bailed out banks were poor monitors prior to the crisis (Purnanandam, 2011).

The results in Tables 8 to 10 show that the positive signal from syndicated bank loans was reduced surrounding the financial crisis. We extend our testing to analyse if the market reaction to syndicated loans has also changed relative to other sources of debt financing. Although we find no evidence of a significant decline in the stock price response to public bond and privately placed debt issues, we formally examine if the change in the stock price response to bank loan announcements is different to the reaction to announcements for alternative sources of debt financing. To do so we estimate regressions of event study CARs separately for pre-crisis and crisis periods. We include dummy variables for each borrowing source type to test differences in the market reaction to loan announcements for the pre-crisis and crisis sub-samples.

We present these results in Table 11. Odd numbered columns present regressions for the pre-crisis period and even numbered columns present crisis period regressions. In Models 1 and 2, we include dummies for public bonds and privately placed debt against the omitted 
group of bank loans. We find that returns are significantly lower for privately placed debt issues only for the pre-crisis period. During the crisis, privately placed debt issuance is no less special than other forms of private debt issuance. This finding is robust to separately analysing syndicated and bilateral loans in Models 3 and 4. Our results in Model 3 provide partial support for Hypothesis 2, where returns to bilateral loan announcements are significantly lower in comparison to the omitted syndicated loans sample during the pre-crisis period. We attribute this to syndicated loans providing monitoring benefits through the lead arranger and the additional scale available through pooled lending within the syndicate (Dennis and Mullineaux, 2000).

\section{[Insert Table 11 about here]}

For illustration, we now change the omitted group of loans and include dummy variables for bank loans (Models 5 and 6) and bilateral and syndicated loans (Models 7 and 8). This allows us to highlight the stock price response to bank loan announcements in comparison to the alternative financing choices we examine. In Model 5, we find that after controlling for firm characteristics, abnormal returns for the full sample of bank loan announcements are insignificantly different to those of public bonds and privately placed debt in the pre-crisis period, and this remains the case during the crisis. In Models 7 and 8, we find that returns are $0.59 \%$ higher for syndicated loans in the pre-crisis period (significant at the 5\% level), but in Model 8 syndicated loans are no longer different to other sources of debt financing during the financial crisis.

Collectively, our findings in this section provide strong support for each of the main hypotheses examined in this paper. For the full sample, we find support for prior US evidence that bank loans are apparently "special" in comparison to alternative sources of borrowing. 
Stock markets react significantly and positively to announcements of bank debt financing, and the sub-sample of syndicated loan announcements drive our results. Our findings suggest that borrowing firms benefit from monitoring by the lead arranger in a syndicated loan and from the certification of being able to borrow relatively larger amounts of capital. However, we find a significant decline in the stock price response to syndicated loan announcements during the global financial crisis to the extent that abnormal returns to syndicated loan announcements are statistically indistinguishable from returns to other sources of debt financing. ${ }^{12}$

\section{Alternative event windows}

We employ some further testing to confirm the robustness of our results. To examine the robustness of our univariate event study results to the use of the market-adjusted model for estimating abnormal returns and to control for potential information leakage prior to the borrowing announcements, in Table 12 we estimate abnormal returns using the both the market model and market-adjusted model over a two-day event window $(-1,0)$ and an alternative three-day event window $(-2,0)$. Our results are robust to the alternative model and to alternative estimation windows.

[Insert Table 12 about here]

\section{Conclusions}

A large body of literature has examined how stock markets respond to announcements of public, bank and privately placed debt issuance in the US. We extend this literature and examine the stock market response to announcements of debt issuance for a sample of 1,537

\footnotetext{
${ }^{12}$ We repeat the regression analysis of Tables 8 to 11 using two-day $(-1,0)$ and three-day $(-2,0)$ market model abnormal return as the dependent variable to ensure and we examine the robustness of our results to the use of the market-adjusted model. Our empirical results remain robust to these tests.
} 
announcements of public, bank and privately placed loans made by UK companies listed on the FTSE-350 index of the London Stock Exchange over the period 2000-2013. We contribute to the literature by separately analysing syndicated and bilateral bank loans, which we expect to elicit a different stock market response. In addition, we examine whether the recent financial crisis has an impact on how the market viewed the announcement of debt offerings from public, bank and privately placed sources.

US studies have traditionally viewed bank loans as being "special" compared to other sources of external debt. Our initial results are consistent with this view. We find no evidence of a significant market reaction to public or privately placed debt announcements, but our event study results show that that the market responds significantly and positively to announcements of bank loans. When we investigate the differences between syndicated and bilateral loans, our findings suggest that syndicated loans drive the positive market response to bank loans and we find no evidence of a positive market reaction to bilateral loans. We interpret our results as showing that the market responds positively to syndicated bank loans where lenders benefit from the monitoring features of traditional bilateral loans and the ability to borrow larger amounts associated with borrowing in public debt markets.

When we consider the implications of the global financial crisis on the market reaction to debt issues, we find lower announcement returns to bank loans made during the more constrained financial climate surrounding this period. The sub-sample of syndicated bank loans again drive our results. Prior to the crisis, abnormal returns to announcements of syndicated bank loans are significantly higher than for other borrowing sources and this relation is no longer present during the crisis. This reflects the damage to the reputation of bank lending as a consequence of poorer credit quality standards and thus poorer lending decisions in the pre-crisis period. 
Our findings have a number of potential implications for lenders, borrowings firms, and market regulators. For lenders, if we attribute subsequent bails outs to poor lending decisions, our finding that stock market returns to bank loan announcements are different for those banks that subsequently received a bail out highlights that markets were aware of poor monitoring standards at the time of the loan announcement. Going forward, this suggests a role for individual lending banks to build a reputation for monitoring in much the same way as investment banks can build reputation in underwriting markets. From the borrower's perspective, if one intention of bank borrowing is to signal to the market its willingness to be monitored then borrowers will choose amongst lenders based on their reputation in performing this role. If securitization of loans and lax lending standards leads to bank lending losing the "special" monitoring benefit identified in US academic literature then we also expect that companies will continue to expand their range of borrowing sources. For smaller and more constrained borrowers, we expect an increasingly important role for the privately placed debt in a firm's capital structure. 


\section{References}

Adrian, T., Colla, P., \& Shin, H.S. (2012). Which financial frictions? Parsing the evidence from the financial crisis of 2007 to 2009. NBER Macroeconomics Annual, 27, 159-214.

Agarwal, S. \& Hauswald, R. (2007). Distance and private information asymmetries in lending decisions. Federal Reserve Bank of Chicago Proceedings (May), 183-204.

Arena, M. P. (2011). The corporate choice between public debt, bank loans, traditional private debt placements, and 144A debt issues. Review of Quantitative Finance \& Accounting, 36, 391-416.

Armitage, S. (1995). Banks' information about borrowers: The stock market response to syndicated loan announcements in the UK. Applied Financial Economics, 5, 449-459.

Bailey, W., Huang, W., \& Yang, Z. (2011). Bank loans with Chinese characteristics: Some evidence on inside debt in a state-controlled banking system. Journal of Financial \& Quantitative Analysis, 46, 1795-1830.

Bank of England. (2009). Trends in lending, August 2009. http://www.bankofengland.co.uk/publications/other/monetary/TrendsAugust09.pdf.

Bank of England. (2012). Trends in lending, October 2012. http://www.bankofengland.co.uk/publications/other/monetary/TrendsOctober12.pdf.

Bank of England. (2013). Trends in lending, January 2013, http://www.bankofengland.co.uk/publications/Documents/other/monetary/trendsjanuary13 .pdf.

Bank of England. (2014). Credit Conditions Survey, 2014. https://www.bankofengland.co.uk/-/media/boe/files/working-paper/2014/the-boe-creditconditions-survey.pdf

Bank of England. (2015). Trends in lending, January 2015, http://www.bankofengland.co.uk/publications/Documents/other/monetary/trendsjanuary15 .pdf.

Barclay, M. J. \& Smith, C. W. (1995). The maturity structure of corporate debt. The Journal of Finance, 50, 609-631.

Bernanke, B. S. (1983). Credit in the macroeconomy. Federal Reserve Bank of New York Quarterly Review.

Billett, M. T., Flannery, M. J., \& Garfinkel, J. A. (1995). The effect of lender identity on a borrowing firm's equity return, The Journal of Finance, 50, 699-718.

Breedon, T. (2012). Boosting finance options for business. London: Department for Business Innovation and Skills.

Caprio, G. (2005), "Foreword" in: P. Honohan, and L. Laeven, eds., Systemic Financial Crisis: Containment and Resolution, Cambridge: Cambridge University Press.

Carbo-Valverde, S., Marques-Ibanez, D. \& Fernandez, F. R. (2011). Securitization, bank lending and credit quality: The Case of Spain. European Central Bank, Working Paper 1329

Chandra, U. \& Nayar, N. (2008). The information content of private debt placements. Journal of Business Finance \& Accounting, 35, 1164-1195.

Curcio, D., De Simone, A., \& Gallo, A. (2017). Financial crisis and international supervision: New evidence on the discretionary use of loan loss provisions at Euro Area commercial banks. The British Accounting Review, 49, 181-193.

De Haas, R. \& van Horen, N. (2010). The crisis as a wake-up call: Do banks tighten screening and monitoring during a financial crisis? European Bank for Research and Development, Working Paper 117.

Degryse, H. \& Ongena, S. (2005). Distance, Lending relationships, and competition. The Journal of Finance, 60, 231-266. 
Denis, D. J. \& Mihov, V. T. (2003). The choice among bank debt, non-bank private debt, and public debt: Evidence from new corporate borrowings. Journal of Financial Economics, 70, 3-28.

Dennis, S. A. \& Mullineaux, D. J. (2000). Syndicated loans. Journal of Financial Intermediation, 9, 404-426.

Diamond, D. W. (1991). Monitoring and reputation: The choice between bank loans and directly placed debt. Journal of Political Economy, 99, 689-721.

Diamond, D. W. (1984). Financial intermediation and delegated monitoring. The Review of Economic Studies, 51, 393-414.

Easterwood, J.C., \& Kadapakkam, P. (1991). The role of private and public debt in corporate capital structures. Financial Management, 20, 49-57.

Fama, E. F. (1985). What's different about banks? Journal of Monetary Economics, 15, 2939.

Faulkender, M. \& Petersen, M. A. (2006). Does the source of capital affect capital structure? Review of Financial Studies, 19, 45-79.

Fery, J., Gasborro, D., Woodliff, D. R. \& Zumwalt, J. K. (2003). Market reaction to published and non-published corporate loan announcements. Quarterly Review of Economics and Finance, 43, 1-10.

Fields, L.P., Fraser, D. R., Berry T. L. \& Byer, S. (2006). Do bank loan relationships still matter? Journal of Money, Credit and Banking, 38, 1195-1209.

Flannert, M. J. (1986). Asymmetric information and risky debt maturity choice. Journal of Finance, 41, 19-37.

Focarelli, D., Pozzolo, A. F. \& Casolaro, L. (2008). The pricing effect of certification on syndicated loans. Journal of Monetary Economics, 55, 335-349.

Fungáčová, Z., Godlweski, C. J. \& Weill, L. (2015). Does the Type of Debt Matter? Stock Market Perception in Europe. Bank of Finland Research Discussion Paper 19 / 2015, Bank of Finland.

Godlewski, C. J. (2014). Bank loans and borrower value during the global financial crisis: Empirical evidence from France. Journal of International Financial Markets, Institutions and Money, 28, 100-130.

Gomes, A. \& Phillips, G. (2012). Why do public firms issue private and public securities? Journal of Financial Intermediation, 21, 619-658.

Hadlock, C. J. \& James, C. M. (2002). Do banks provide financial slack? The Journal of Finance, 57, 1383-1419.

Hauswald, R. \& Marquez, R. (2005). Competition and strategic information acquisition in credit markets. Review of Financial Studies, 19, 967-1000.

Ho, T. S. Y. \& Singer, R. F. (1982). Bond indenture provisions and the risk of corporate debt. Journal of Financial Economics, 10, 375-406.

Hoshi, T, Kashyap, A., \& Scharfstein, D. (1993). The choice between public and private debt: An analysis of post-deregulation corporate financing in Japan, NBER working paper Series, 4421.

Huang, W., Schwienbacher, A. \& Zhao, S. (2012). When bank loans are bad news: Evidence from market reactions to loan announcements under the risk of expropriation. Journal of International Financial Markets, Institutions and Money, 22, 233-252.

International Financial Law Review. (2013). What's holding back UK private placements? http://www.iflr.com/Article/3164106/Whats-holding-back-UK-private-placements.html.

James, C. M. (1987). Some evidence on the uniqueness of bank loans. Journal of Financial Economics, 19, 217-235.

Johnson, S. A. (1995). Dividend payout and the valuation effects of bond announcements. Journal of Financial \& Quantitative Analysis, 30, 407-423. 
Johnson, S. A. (1997). An empirical analysis of the determinants of corporate debt ownership structure. Journal of Financial \& Quantitative Analysis, 32, 47-69.

Kolari, J. W. \& Pynnönen, S. (2010). Event study testing with cross-sectional correlation of abnormal returns, Review of Financial Studies, 23, 3996-4025.

Lee, K-W. \& Sharpe, I. G. (2009). Does a bank's loan screening and monitoring matter? Journal of Financial Services Research, 35, 33-52.

Li, C. \& Ongena, S. (2015). Bank loan announcements and borrower stock returns before and during the recent financial crisis. Journal of Financial Stability, 21, 1-12.

Lummer, S.L. \& McConnell, J.J. (1989). Further evidence on the bank lending process and the capital-market response to bank loan agreements', Journal of Financial Economics, 25, 99-122.

Marshall, A., McCann, L. \& McColgan, P. (2016). The choice of debt source by UK firms. Journal of Business Finance \& Accounting, 43, 729-764.

Maskara, P. K. \& Mullineaux, D. J. (2011). Information asymmetry and self-selection bias in bank loan announcement studies. Journal of Financial Economics, 101, 684-694.

Mikkelson, W. H. \& Partch, M. M. (1986). Valuation effects of security offerings and the issuance process. Journal of Financial Economics, 15, 31-60.

Nakamura, L. I. (1993). Monitoring loan quality via checking account analysis. Journal of Retail Banking, 14, 16-34.

National Audit Office. (2011). The financial stability interventions. July 2011. https://www.nao.org.uk/wp-content/uploads/2011/07/HMT_account_2010_2011.pdf.

Preece, D. C. \& Mullineaux, D. J. (1994). Monitoring by financial intermediaries: Banks vs. nonbanks. Journal of Financial Services Research, 8, 193-202.

Purnanandam, A. (2011). Originate-to-distribute model and the subprime mortgage crisis. Review of Financial Studies, 24, 1881-1915.

Shepherd, J., Tung, F., \& Yoon, A. (2007). Cross monitoring and corporate governance, Working Paper, Emory University

Slaughter and May. (2014). Breedon +2 years: where are we now? Current non-bank lending options for UK corporates. http://www.slaughterandmay.com/media/2182575/breedonplus-2-years-where-are-we-now.pdf.

Slovin, M. C., Johnson, S. A. \& Glascock J. L. (1992). Firm size and the information content of bank loan announcements. Journal of Banking and Finance, 16, 1057-1071.

Slovin, M. C., Sushka, M. E. \& Lai, K. W. (2000). Alternative flotation methods, adverse selection, and ownership structure: evidence from seasoned equity issuance in the U.K. Journal of Financial Economics, 57, 157-190.

Sufi, A. (2007). Information asymmetry and financing arrangements: Evidence from syndicated loans. The Journal of Finance, 17, 629-668. 


\section{Figure 1}

Existing Debt Mix

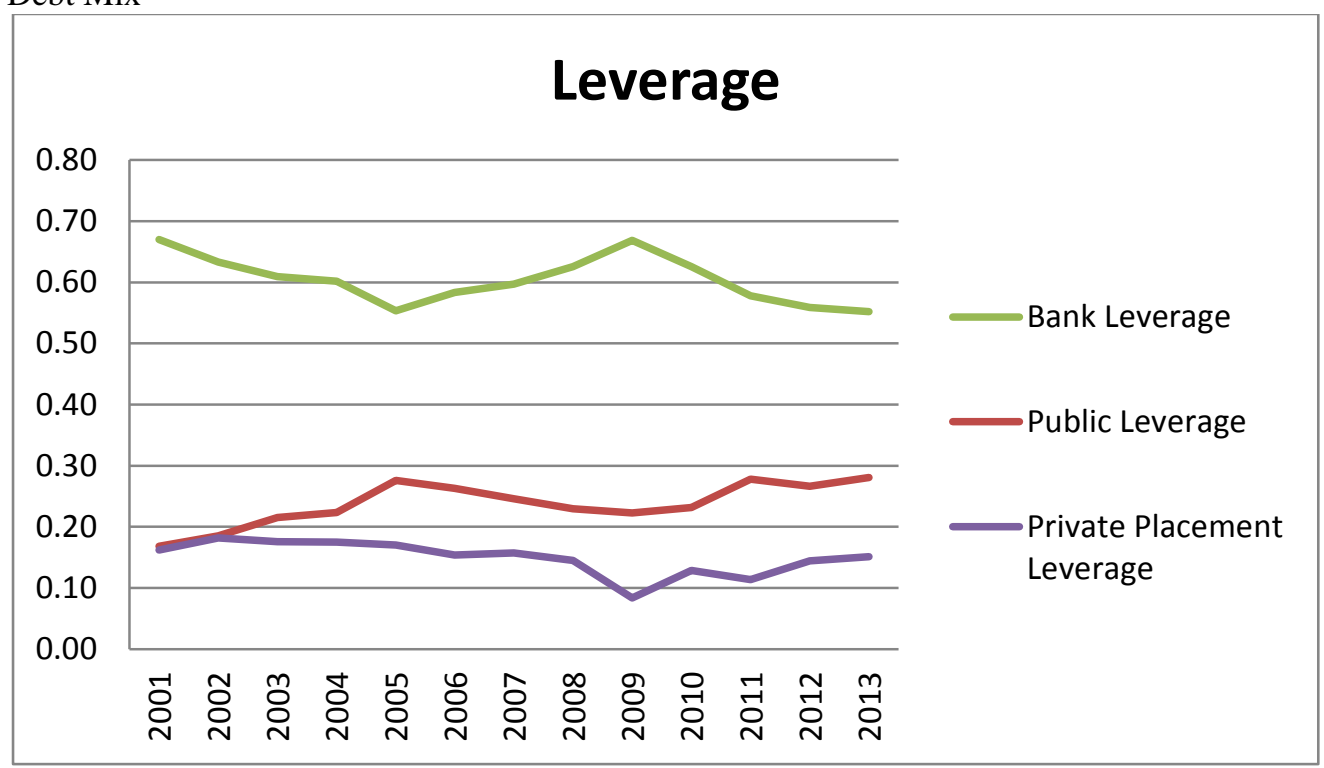

This figure reports the existing debt mix for non-financial and non-utility companies whose shares were included in the FTSE-350 index of the London Stock Exchange at any time during the period 2000-2012. Data on corporate borrowing from public, bank, and privately placed lenders is collected from the footnotes to the financial statements for each firm-year. Public leverage, bank leverage and private placement leverage are defined as the ratio of debt from each source divided by total debt outstanding. 
Table 1

Description of variables.

\begin{tabular}{ll}
\hline Variable & Description \\
\hline Panel A: Debt announcements & \\
CRISIS & $\begin{array}{l}\text { A dummy variable set equal to } 1 \text { for announcements } \\
\text { made on or after January 1st 2008, and zero otherwise. }\end{array}$
\end{tabular}

LOAN SIZE The amount borrowed.

MATURITY The years to maturity of the loan.

announcement states that the loan is a renewal, revision, renegotiation or extension of an existing

credit agreement, and zero otherwise.
A dummy variable set equal to one for loans where the

REFINANCE announcement notes that the stated use of proceeds is to refinance existing debt, and zero otherwise.

A dummy variable set equal to one for loans where the ACQUISITION announcement notes that the stated use of proceeds is to finance acquisitions, and zero otherwise.

A dummy variable set equal to one for loans where the OTHER anncement notes the stated use of proceeds is not to refinance existing debt or to finance acquisitions, and zero otherwise.

A dummy variable set equal to one for loans where the UNCLASSIFIED announcement does not state the intended use of proceeds for the loan, and zero otherwise.

Panel B: Firm characteristics

\section{ASSETS Book value of total assets in £bn.}

FIXED ASSETS The ratio of net plant, property, and equipment to total

RATIO assets.

FIRM AGE Number of years since incorporation.

LEVERAGE Book value of total debt divided by book value of total assets.

The daily buy-and-hold return over the firm's

BHAR accounting year minus the return on the FTSE-350 index over the same time period.

Panel C: Lender Quality Characteristics

A dummy variable set equal to one for loans where the

UK LENDER lending bank's headquarters are located in the UK, and zero otherwise. For syndicated loans we focus on the headquarter location of the lead arranger.

LENDER A dummy variable set equal to one for loans where the BAILOUT lending bank received a government bailout during the financial crisis, and zero otherwise.

LENDER CREDIT A dummy variable set equal to one for loans where the RATING lending bank had a S\&P credit rating of AA or above lending bank had a S\&P credit rating of AA or above
at the time of the loan agreement, and zero otherwise.

Source

Datastream, DealScan, Nexis UK, Private Placement Letter and ThomsonOne

Datastream, DealScan, Nexis

UK, Private Placement Letter and ThomsonOne

Datastream, DealScan, Nexis UK, Private Placement Letter and ThomsonOne

Datastream, Nexis UK, Private Placement Letter and ThomsonOne

Datastream, DealScan, Nexis UK, Private Placement Letter and ThomsonOne

Datastream, DealScan, Nexis UK, Private Placement Letter and ThomsonOne

Datastream, DealScan, Nexis UK, Private Placement Letter and ThomsonOne

Datastream, DealScan, Nexis UK, Private Placement Letter and ThomsonOne

Worldscope

Worldscope

Worldscope

Worldscope

Worldscope

Annual Reports, DealScan, Nexis UK, and ThomsonOne

National Audit Office (2011), Nexis UK

ThomsonOne

The table reports variable definitions for debt and firm characteristics for our sample of loan announcements. Data is for 1,537 debt announcements for non-financial and non-utility companies whose shares were included in the FTSE-350 index of the London Stock Exchange during the period 2000-2012. Debt announcements take place in the subsequent year. 
Table 2

Distribution of debt announcements over time.

\begin{tabular}{|c|c|c|c|c|c|c|c|c|c|c|}
\hline \multirow[b]{2}{*}{ Year } & \multicolumn{2}{|c|}{ Public Bonds } & \multicolumn{2}{|c|}{ Bank Loans } & \multicolumn{2}{|c|}{ Syndicated Loans } & \multicolumn{2}{|c|}{ Bilateral Loans } & \multicolumn{2}{|c|}{ Privately placed Debt } \\
\hline & No. & $\%$ & No. & $\%$ & No. & $\%$ & No. & $\%$ & No. & $\%$ \\
\hline 2001 & 53 & [14.32\%] & 49 & [5.07\%] & 42 & [5.48\%] & 7 & {$[3.50 \%]$} & 21 & [10.50\%] \\
\hline 2002 & 41 & [11.08\%] & 49 & {$[5.07 \%]$} & 43 & {$[5.61 \%]$} & 6 & {$[3.00 \%]$} & 22 & [11.00\%] \\
\hline 2003 & 42 & [11.35\%] & 64 & [6.62\%] & 61 & [7.95\%] & 3 & {$[1.50 \%]$} & 25 & [12.50\%] \\
\hline 2004 & 42 & [11.35\%] & 90 & [9.31\%] & 80 & [10.43\%] & 10 & {$[5.00 \%]$} & 12 & {$[6.00 \%]$} \\
\hline 2005 & 21 & [5.68\%] & 105 & [10.86\%] & 86 & [11.21\%] & 19 & [9.50\%] & 9 & {$[4.50 \%]$} \\
\hline 2006 & 38 & [10.27\%] & 75 & {$[7.76 \%]$} & 67 & {$[8.74 \%]$} & 8 & [4.00\%] & 21 & [10.50\%] \\
\hline 2007 & 35 & {$[9.46 \%]$} & 74 & [7.65\%] & 62 & [8.08\%] & 12 & [6.00\%] & 19 & {$[9.50 \%]$} \\
\hline 2008 & 31 & {$[8.38 \%]$} & 64 & {$[6.62 \%]$} & 48 & {$[6.26 \%]$} & 16 & {$[8.00 \%]$} & 16 & {$[8.00 \%]$} \\
\hline 2009 & 20 & [5.41\%] & 58 & [6.00\%] & 40 & [5.22\%] & 18 & [9.00\%] & 13 & [6.50\%] \\
\hline 2010 & 10 & [2.70\%] & 84 & [8.69\%] & 66 & {$[8.60 \%]$} & 18 & {$[9.00 \%]$} & 14 & [7.00\%] \\
\hline 2011 & 11 & [2.97\%] & 117 & {$[12.10 \%]$} & 82 & [10.69\%] & 35 & {$[17.50 \%]$} & 11 & {$[5.50 \%]$} \\
\hline 2012 & 15 & [4.05\%] & 72 & {$[7.45 \%]$} & 45 & {$[5.87 \%]$} & 27 & {$[13.50 \%]$} & 9 & {$[4.50 \%]$} \\
\hline 2013 & 11 & [2.97\%] & 66 & [6.83\%] & 45 & {$[5.87 \%]$} & 21 & {$[10.50 \%]$} & 8 & [4.00\%] \\
\hline Pre-crisis period (2001-2007) & 272 & [73.51\%] & 506 & {$[52.33 \%]$} & 441 & {$[57.50 \%]$} & 65 & {$[32.50 \%]$} & 129 & {$[64.50 \%]$} \\
\hline Crisis period $(2008-2013)$ & 98 & {$[26.49 \%]$} & 461 & {$[47.67 \%]$} & 326 & {$[42.50 \%]$} & 135 & {$[67.50 \%]$} & 71 & {$[35.50 \%]$} \\
\hline Total & 370 & [100.00\%] & 967 & {$[100.00 \%]$} & 767 & {$[100.00 \%]$} & 200 & {$[100.00 \%]$} & 200 & {$[100.00 \%]$} \\
\hline
\end{tabular}

$\chi^{2}$ test that the proportion of debt announcements in the pre-crisis period is equal to the corresponding proportions in the crisis period on the assumption that loans are equally distributed annually.

\begin{tabular}{|c|c|c|c|c|}
\hline $\begin{array}{l}81.83 * * * \\
(0.0000)\end{array}$ & $\begin{array}{l}2.09 \\
(0.1480)\end{array}$ & $\begin{array}{l}17.24 * * * \\
(0.0000)\end{array}$ & $\begin{array}{l}24.50 * * * \\
(0.0000)\end{array}$ & $\begin{array}{l}16.82 * * * \\
(0.0000)\end{array}$ \\
\hline
\end{tabular}

The table reports the distribution [percentage] of debt announcements for our sample by debt source by year. Results are reported separately for issuance of public bonds, syndicated bank loans, bilateral bank loans, and privately placed debt. The pre-crisis period includes all debt announcements from 2001 to 2007 . The crisis period includes all debt announcements from 2008 to 2013 . $^{* * *}$ and ${ }^{* *}$ denote statistical significance at the $1 \%$ and $5 \%$ level respectively. 
Table 3

Summary statistics for debt announcements.

\begin{tabular}{|c|c|c|c|c|c|c|c|c|c|c|}
\hline & \multicolumn{2}{|c|}{ Public Bonds } & \multicolumn{2}{|c|}{ Bank Loans } & \multicolumn{2}{|c|}{ Syndicated Loans } & \multicolumn{2}{|c|}{ Bilateral Loans } & \multicolumn{2}{|c|}{ Privately placed Debt } \\
\hline & No. & Mean & No. & Mean & No. & Mean & No. & Mean & No. & Mean \\
\hline LOAN SIZE $(£ m)$ & 350 & 277.80 & 872 & 397.20 & 686 & 447.39 & 186 & 212.10 & 185 & 96.99 \\
\hline LOAN SIZE / ASSETS & 338 & 0.09 & 824 & 0.22 & 653 & 0.22 & 171 & 0.2 & 181 & 0.07 \\
\hline LOAN MATURITY & 338 & 12.58 & 838 & 3.94 & 679 & 3.91 & 159 & 4.05 & 180 & 8.75 \\
\hline ASSETS (£bn) & 365 & 13.14 & 953 & 3.91 & 757 & 3.36 & 196 & 6.03 & 199 & 2.86 \\
\hline FIXED ASSETS RATIO & 362 & 0.35 & 942 & 0.3 & 746 & 0.3 & 196 & 0.3 & 198 & 0.25 \\
\hline FIRM AGE & 361 & 49.25 & 934 & 42.05 & 742 & 43.47 & 192 & 36.55 & 199 & 48.46 \\
\hline LEVERAGE & 365 & 4.52 & 952 & 16.15 & 756 & 16.08 & 196 & 16.45 & 199 & 3.42 \\
\hline BHAR & 352 & 0.12 & 907 & 0.15 & 722 & 0.15 & 185 & 0.16 & 187 & 0.12 \\
\hline
\end{tabular}

The table reports summary statistics for our sample of loan announcements. The sample and all variables are defined in Table 1. 
Table 4

Cumulative average abnormal returns (\%) surrounding debt announcements.

\begin{tabular}{|c|c|c|c|c|c|}
\hline & Public Bonds & Bank Loans & $\begin{array}{c}\text { Syndicated } \\
\text { Loans }\end{array}$ & $\begin{array}{c}\text { Bilateral } \\
\text { Loans }\end{array}$ & $\begin{array}{c}\text { Privately } \\
\text { placed Debt }\end{array}$ \\
\hline \multicolumn{6}{|c|}{$\begin{array}{l}\text { Panel A: Univariate event study results } \\
\text { Market model returns }\end{array}$} \\
\hline $\operatorname{CAAR}(-1,+1)$ & $\begin{array}{c}0.18 \\
(0.83) \\
{[0.67]}\end{array}$ & $\begin{array}{c}0.56 \\
(2.55)^{* *} \\
{[2.74]^{* * *}}\end{array}$ & $\begin{array}{c}0.57 \\
(2.35)^{* *} \\
{[2.23]^{* *}}\end{array}$ & $\begin{array}{c}0.50 \\
(1.01) \\
{[1.47]}\end{array}$ & $\begin{array}{c}-0.16 \\
(-0.60) \\
{[-0.68]}\end{array}$ \\
\hline \multicolumn{6}{|c|}{ Market-adjusted model returns } \\
\hline CAAR $(-1,+1)$ & $\begin{array}{c}0.29 \\
(1.32) \\
{[1.63]} \\
370\end{array}$ & $\begin{array}{c}0.65 \\
(2.98)^{* * *} \\
{[3.17]^{* * *}} \\
967\end{array}$ & $\begin{array}{c}0.69 \\
(2.82)^{* * *} \\
{[2.58]^{* *}} \\
767\end{array}$ & $\begin{array}{c}0.52 \\
(1.05) \\
{[1.65]} \\
200\end{array}$ & $\begin{array}{c}0.13 \\
(0.50) \\
{[-0.87]} \\
200\end{array}$ \\
\hline \multicolumn{6}{|c|}{ Panel B: T-statistics for difference in abnormal returns for different debt types } \\
\hline & Public Bonds & $\begin{array}{c}\text { Privately } \\
\text { placed Debt }\end{array}$ & $\begin{array}{c}\text { Bilateral } \\
\text { Loans }\end{array}$ & & \\
\hline Bank Loans & 1.20 & $2.09 * *$ & & & \\
\hline Syndicated Loans & 1.18 & $2.04 * *$ & 0.13 & & \\
\hline
\end{tabular}

The table reports three-day cumulative average abnormal returns (CAARs) centred on the announcement day, zero for a sample of debt announcements. Market model and market-adjusted model returns are estimated using a 170-day estimation window beginning on day -200 relative to the event day. The FTSE 350 index is used as the market benchmark for estimating CARs. The sample and all variables are defined in Table $1 .{ }^{* * *}$ and ${ }^{* *}$ denote statistical significance at the $1 \%$ and $5 \%$ level respectively. T-statistics are reported in parentheses and Kolari and Pynnönen (2010) corrected t-tests are presented in brackets. 
Table 5

Debt and borrower summary statistics.

Public

Bank

Syndicated

Bilateral

Privately

Bonds

Loans

Loans

Loans

Debt

Panel A: Debt characteristics

Pre-crisis period (2001-2007):

Number of observations

LOAN SIZE (£m)

LOAN SIZE / ASSETS

LOAN MATURITY

13.

$\begin{array}{lllll}0.01 & 0.13 & 0.12 & 0.23 & 0.01\end{array}$

- RENEWAL

Use of Proceeds:

- REFINANCING

$\begin{array}{lllll}0.28 & 0.44 & 0.46 & 0.32 & 0.22 \\ 0.07 & 0.23 & 0.24 & 0.21 & 0.02 \\ 0.09 & 0.06 & 0.04 & 0.18 & 0.46 \\ 0.60 & 0.34 & 0.34 & 0.29 & 0.38\end{array}$

- ACQUISITION

- OTHER

- UNCLASSIFIED

Crisis period (2008-2013):

Number of observations

$\begin{array}{ccccc}98 & 461 & 326 & 135 & 71 \\ 279.27 & 376.18 & 440.53 & 222.31 & 108.12 \\ 0.06 * * * & 0.22 & 0.22 & 0.21 & 0.08 \\ 10.22 * * & 3.82 * * & 3.77 * * & 3.93 & 8.55 * * \\ & & & & \\ 0.00 & 0.15 & 0.16 & 0.11 & 0.00\end{array}$

LOAN SIZE (£m)

LOAN SIZE / ASSETS

LOAN MATURITY

Loan Status:

- RENEWAL

$\begin{array}{lllll}0.15 * * * & 0.37 * * & 0.35 * * * & 0.39 & 0.13\end{array}$

- REFINANCING

$\begin{array}{lllll}0.02 * * & 0.13 * * * & 0.12 * * * & 0.16 & 0.01\end{array}$

- ACQUISITION

$0.68 * * * \quad 0.46 * * * \quad 0.50 * * *$

$0.39 * * *$

$0.13 * * *$

- UNCLASSIFIED

$0.14 * * * \quad 0.04 * * *$

$0.03 * * *$

$0.07 * * *$

$0.73 * * *$ 
Table 5 (continued)

Panel B: Firm characteristics

Pre-crisis period (2001-2007):

ASSETS (£bn)

$\begin{array}{ccccc}10.60 & 4.17 & 3.07 & 11.76 & 2.96 \\ 0.38 & 0.31 & 0.30 & 0.33 & 0.28 \\ 51.01 & 43.33 & 45.2 & 29.71 & 51.29 \\ 0.36 & 0.31 & 0.31 & 0.28 & 0.31 \\ 0.13 & 0.18 & 0.16 & 0.30 & 0.12\end{array}$

Crisis period (2008-2013):

ASSETS (£bn)

$20.05 * * *$

3.62

3.77

3.19

FIXED ASSETS RATIO

$0.29 * * *$

0.29

0.29

0.28

$0.18 * * *$

FIRM AGE

$\begin{array}{lllll}44.10 & 40.61 & 41.05 & 39.82 & 43.24\end{array}$

LEVERAGE

$\begin{array}{lllll}15.86 * * & 33.76 * * * & 37.67 * * * & 24.48 * * * & 9.14\end{array}$

BHAR

0.09

0.12

0.13

$0.09 * *$

0.13

Panel C: Lender quality characteristics

Pre-crisis period (2001-2007):

UK LENDER

$\begin{array}{ccc}0.66 & 0.66 & 0.63 \\ 0.51 & 0.51 & 0.55 \\ 1 & 1 & 1\end{array}$

LENDER CREDIT RATING

Crisis period (2008-2013):

UK LENDER

$\begin{array}{lll}0.63 & 0.63 & 0.63\end{array}$

LENDER BAILOUT

$0.65 * * * \quad 0.67 * * * \quad 0.60$

LENDER CREDIT RATING

$0.96 * * * \quad 0.96 * * * \quad 0.96$

The table reports mean summary statistics for loan and firm characteristics for our sample debt announcements. The stated use of loan proceeds is not mutually exclusive. The pre-crisis period includes all loan announcements from 2001 to 2007. The crisis period includes all loan announcements from 2008 to 2013. The sample and all variables are defined in Table $1 .{ }^{* * *}$ and ${ }^{* *}$ denote statistical significance at the $1 \%$ and $5 \%$ level respectively for the difference in sample means between the pre-crisis and crisis time periods for two-tailed t-tests of means. 
Table 6

Cumulative average abnormal returns (\%) surrounding debt announcements.

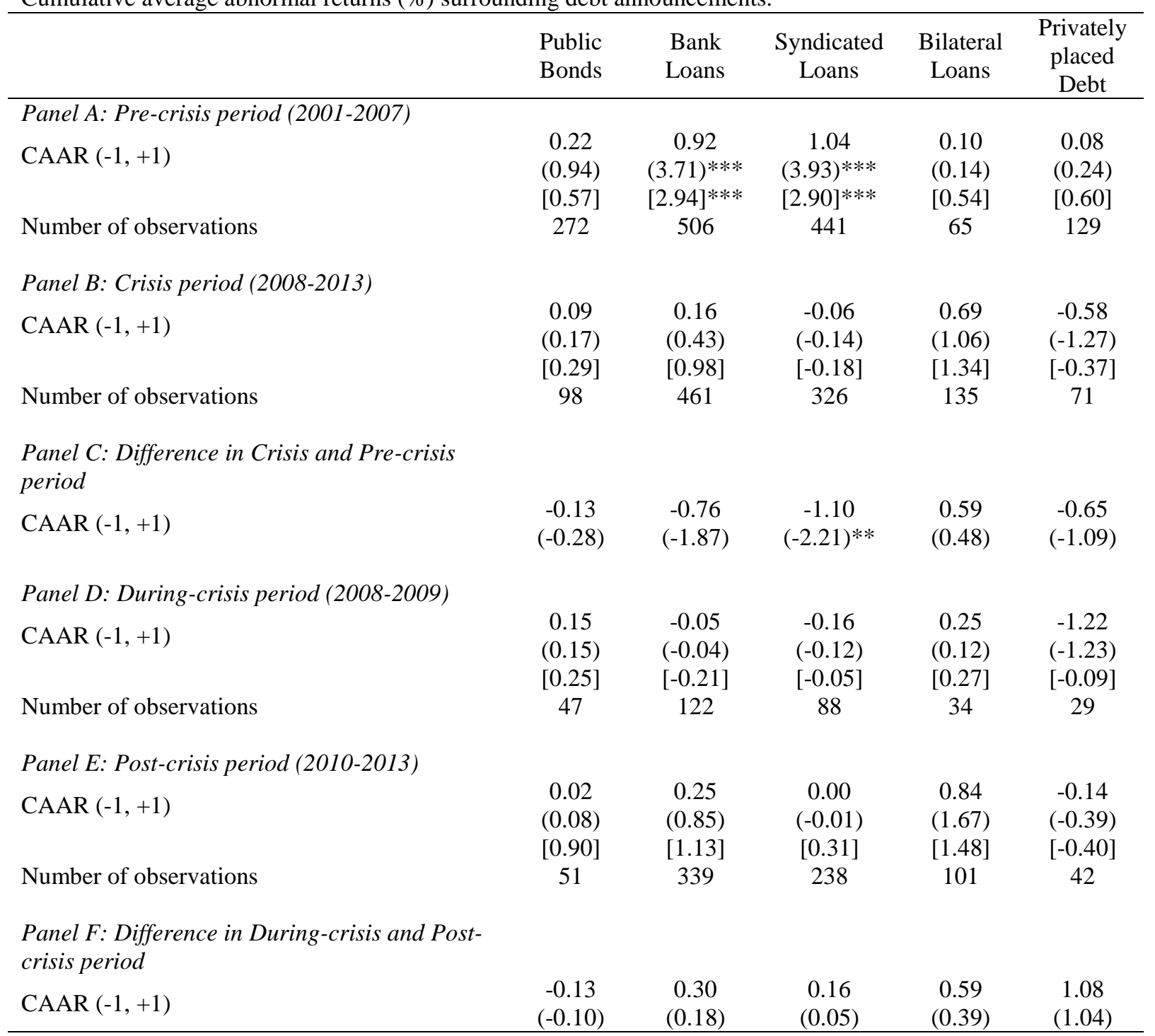

The table reports three-day cumulative average abnormal returns (CAARs) centred on the announcement day, zero for a sample of debt announcements. Market model returns are estimated using a 170-day estimation window beginning on day -200 relative to the event day. The FTSE 350 index is used as the market benchmark for estimating CARs using the market model. The sample and all variables are defined in Table $1 .{ }^{* * *}$ and ${ }^{* *}$ denote statistical significance at the $1 \%$ and $5 \%$ level respectively. T-statistics are reported in parentheses and Kolari and Pynnönen (2010) corrected t-tests are presented in brackets. 
Table 7

Cumulative average abnormal returns (\%) surrounding debt announcements.

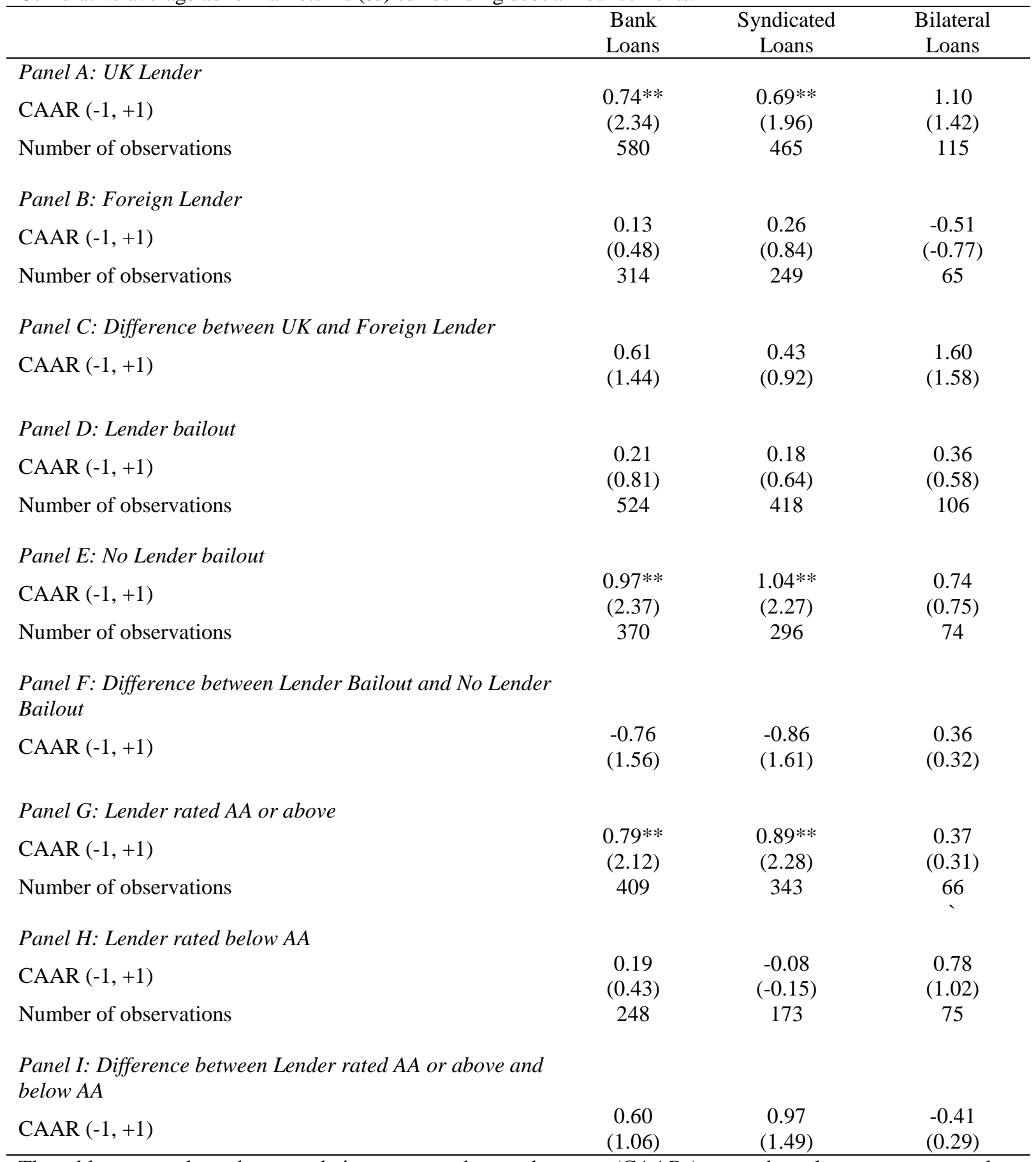

The table reports three-day cumulative average abnormal returns (CAARs) centred on the announcement day, zero for a sample of debt announcements. Market model returns are estimated using a 170-day estimation window beginning on day -200 relative to the event day. The FTSE 350 index is used as the market benchmark for estimating CARs using the market model. The sample and all variables are defined in Table $1^{* * *}$ and ${ }^{* *}$ denote statistical significance at the $1 \%$ and $5 \%$ level respectively. T-statistics are reported in parentheses. 
Table 8

Difference in abnormal returns surrounding the financial crisis classified by borrowing source.

\begin{tabular}{lccccc}
\hline Borrowing source & Public Bonds & Bank Loans & $\begin{array}{c}\text { Syndicated } \\
\text { Loans }\end{array}$ & $\begin{array}{c}\text { Bilateral } \\
\text { Loans }\end{array}$ & $\begin{array}{c}\text { Privately } \\
\text { placed Debt }\end{array}$ \\
\hline Intercept & $(1)$ & $(2)$ & $(3)$ & $(4)$ & $(5)$ \\
& 0.0264 & $0.0952^{* * *}$ & $0.1047 * * *$ & 0.0671 & 0.0032 \\
& $(0.65)$ & $(3.40)$ & $(3.10)$ & $(1.56)$ & $(0.06)$ \\
CRISIS & -0.0008 & $-0.009)^{* *}$ & $-0.0140^{* * *}$ & 0.0079 & -0.0027 \\
& $(-0.11)$ & $(-2.183)$ & $(-2.70)$ & $(0.88)$ & $(-0.53)$ \\
Ln TA & & & & -0.0030 & -0.0001 \\
& -0.0015 & $-0.0040^{* * *}$ & $-0.0044^{* * *}$ & $(-1.69)$ & $(-0.06)$ \\
LEVERAGE & $(-0.87)$ & $(-3.49)$ & $(-3.13)$ & -0.0001 & -0.0000 \\
FIXED ASSETS & 0.0000 & -0.0001 & -0.0001 & $(-1.14)$ & $(-0.77)$ \\
RATIO & $(0.00)$ & $(-1.56)$ & $(-1.33)$ & -0.0134 & 0.0013 \\
Ln FIRM AGE & 0.01168 & -0.00294 & 0.0006 & $(-0.93)$ & $(0.11)$ \\
& $(1.30)$ & $(-0.40)$ & $(0.07)$ & -0.0007 & -0.0002 \\
BHAR & 0.0012 & 0.0001 & -0.0001 & $(-0.19)$ & $(-0.10)$ \\
& $(0.73)$ & $(0.06)$ & $(-0.04)$ & -0.0048 & 0.0057 \\
Number of & -0.0001 & -0.0054 & -0.0054 & $(-0.81)$ & $(0.48)$ \\
observations & $(-0.01)$ & $(-1.06)$ & $(-0.84)$ & & 177 \\
R-squared & & & & 0.0149 & 0.0070 \\
F-statistic & 340 & 871 & 694 & 1.02 & 0.33
\end{tabular}

The table reports OLS regressions of abnormal returns surrounding debt announcements. The dependent variable is the three-day market model abnormal return centred on the announcement day, zero. The sample and all variables are defined in Table 1. T-statistics for standard errors clustered by issuing firm are reported in parenthesis. ${ }^{* * *}$ and ${ }^{* *}$ denote statistical significance at the $1 \%$ and $5 \%$ level respectively. 
Table 9

Difference in abnormal returns surrounding the financial crisis controlling for borrowing firm, lender quality and loan characteristics.

\begin{tabular}{|c|c|c|c|c|c|c|c|c|}
\hline & $(1)$ & $(2)$ & (3) & $(4)$ & $(5)$ & $(6)$ & $(7)$ & $(8)$ \\
\hline Intercept & $\begin{array}{c}0.0973 \\
(1.61)\end{array}$ & $\begin{array}{c}0.0882 * * * \\
(2.72)\end{array}$ & $\begin{array}{c}0.1031 * * * \\
(3.05)\end{array}$ & $\begin{array}{c}0.0985 * * * \\
(2.89)\end{array}$ & $\begin{array}{c}0.1032 * * * \\
(3.07)\end{array}$ & $\begin{array}{c}0.1117 * * * \\
(3.18)\end{array}$ & $\begin{array}{c}0.1044 * * * \\
(2.86)\end{array}$ & $\begin{array}{c}0.1319 * * \\
(2.51)\end{array}$ \\
\hline CRISIS & $\begin{array}{c}-0.0112^{* *} \\
(-2.30)\end{array}$ & $\begin{array}{c}-0.0106 * * \\
(-2.10)\end{array}$ & $\begin{array}{c}-0.0143 * * * \\
(-2.72)\end{array}$ & $\begin{array}{c}-0.0128 * * \\
(-2.52)\end{array}$ & $\begin{array}{c}-0.0143^{* * * *} \\
(-2.69)\end{array}$ & $\begin{array}{c}-0.0151 * * * \\
(-2.75)\end{array}$ & $\begin{array}{c}-0.0142 * * \\
(-2.40)\end{array}$ & $\begin{array}{c}-0.0154 \\
(-1.27)\end{array}$ \\
\hline Ln TA & $\begin{array}{c}-0.0042 \\
(-1.79)\end{array}$ & $\begin{array}{c}-0.0038 * * * \\
(-2.86)\end{array}$ & $\begin{array}{c}-0.0044 * * * \\
(-3.09)\end{array}$ & $\begin{array}{c}-0.0043 * * * \\
(-3.03)\end{array}$ & $\begin{array}{c}-0.0042 * * * \\
(-2.97)\end{array}$ & $\begin{array}{c}-0.0046^{* * * *} \\
(-3.05)\end{array}$ & $\begin{array}{c}-0.0042 * * * \\
(-2.86)\end{array}$ & $\begin{array}{c}-0.0055^{* *} \\
(-2.45)\end{array}$ \\
\hline LEVERAGE & $\begin{array}{c}-0.0003 * * * \\
(-3.81)\end{array}$ & $\begin{array}{l}0.0000 \\
(-1.22)\end{array}$ & $\begin{array}{c}-0.0001 \\
(-1.29)\end{array}$ & $\begin{array}{c}-0.0001 \\
(-1.26)\end{array}$ & $\begin{array}{c}-0.0001 \\
(-1.32)\end{array}$ & $\begin{array}{c}-0.0001 \\
(-1.42)\end{array}$ & $\begin{array}{c}-0.0001 \\
(-1.35)\end{array}$ & $\begin{array}{c}-0.0002 \\
(-1.48)\end{array}$ \\
\hline FIXED ASSETS RATIO & $\begin{array}{c}-0.0036 \\
(-0.45)\end{array}$ & $\begin{array}{c}-0.0057 \\
(-0.66)\end{array}$ & $\begin{array}{c}0.0004 \\
(0.05)\end{array}$ & $\begin{array}{c}0.0021 \\
(0.26)\end{array}$ & $\begin{array}{c}0.0003 \\
(0.04)\end{array}$ & $\begin{array}{c}0.0014 \\
(0.16)\end{array}$ & $\begin{array}{c}-0.0008 \\
(-0.10)\end{array}$ & $\begin{array}{c}-0.0004 \\
(-0.04)\end{array}$ \\
\hline Ln FIRM AGE & $\begin{array}{l}0.001 \\
(0.34)\end{array}$ & $\begin{array}{c}0.0007 \\
(0.25)\end{array}$ & $\begin{array}{c}-0.0001 \\
(-0.04)\end{array}$ & $\begin{array}{c}0.0001 \\
(0.02)\end{array}$ & $\begin{array}{c}-0.0001 \\
(-0.04)\end{array}$ & $\begin{array}{c}-0.0004 \\
(-0.13)\end{array}$ & $\begin{array}{l}-0.0006 \\
(-0.22)\end{array}$ & $\begin{array}{c}-0.0003 \\
(-0.07)\end{array}$ \\
\hline BHAR & $\begin{array}{c}-0.0079 \\
(-1.22)\end{array}$ & $\begin{array}{c}-0.0014 \\
(-0.19)\end{array}$ & $\begin{array}{c}-0.0054 \\
(-0.85)\end{array}$ & $\begin{array}{l}-0.0056 \\
(-0.87)\end{array}$ & $\begin{array}{c}-0.0054 \\
(-0.84)\end{array}$ & $\begin{array}{l}-0.0088 \\
(-1.25)\end{array}$ & $\begin{array}{c}-0.0088 \\
(-1.26)\end{array}$ & $\begin{array}{c}-0.0131 \\
(-1.57)\end{array}$ \\
\hline LOAN SIZE / ASSETS & $\begin{array}{c}-0.0024 \\
(-0.12)\end{array}$ & & & & & & & \\
\hline LOAN MATURITY & & $\begin{array}{l}0.0000 \\
(0.02)\end{array}$ & & & & & & \\
\hline RENEWAL & & & $\begin{array}{l}0.0056 \\
(0.87)\end{array}$ & & & & & \\
\hline ACQUISITION & & & & $\begin{array}{r}0.0094 \\
(1.60)\end{array}$ & & & & \\
\hline REFINANCE DEBT & & & & & $\begin{array}{l}-0.0062 \\
(-1.15)\end{array}$ & & & \\
\hline UK LENDER & & & & & & $\begin{array}{c}-0.0038 \\
(-0.72)\end{array}$ & & \\
\hline LENDER BAIL OUT & & & & & & & $\begin{array}{c}-0.0046 \\
(-0.79)\end{array}$ & \\
\hline $\begin{array}{l}\text { LENDER CREDIT } \\
\text { RATING }\end{array}$ & & & & & & & & $\begin{array}{c}-0.0004 \\
(-0.04)\end{array}$ \\
\hline Number of observations & 618 & 620 & 694 & 694 & 694 & 655 & 655 & 464 \\
\hline R-squared & 0.0229 & 0.0157 & 0.0233 & 0.0254 & 0.0246 & 0.0261 & 0.0266 & 0.0331 \\
\hline F-statistic & $43.31 * * *$ & 1.78 & $2.14 * *$ & $2.46 * *$ & $2.14 * *$ & 2.16 & $2.49 * *$ & 1.93 \\
\hline
\end{tabular}


The table reports OLS regressions of abnormal returns surrounding loan announcements. The dependent variable is the three-day market model abnormal return centred on the announcement day, zero. The sample and all variables are defined in Table 1 . T-statistics for standard errors clustered by issuing firm are reported in parenthesis. ${ }^{* * *}$ and ${ }^{*}$ denote statistical significance at the $1 \%$ and $5 \%$ level respectively. 
Table 10

Difference in abnormal returns surrounding the financial crisis controlling for the interaction effects between lender characteristics and the crisis period.

\begin{tabular}{|c|c|c|c|}
\hline & $(1)$ & $(2)$ & $(3)$ \\
\hline Intercept & $\begin{array}{c}0.0964 * * * \\
(3.13)\end{array}$ & $\begin{array}{c}0.1005^{* * *} \\
(2.99)\end{array}$ & $\begin{array}{c}0.1255^{* *} \\
(2.33)\end{array}$ \\
\hline CRISIS & $\begin{array}{c}-0.0100 \\
(-1.50)\end{array}$ & $\begin{array}{c}-0.0330 * * * \\
(-2.78)\end{array}$ & $\begin{array}{c}-0.0095 \\
(-1.14)\end{array}$ \\
\hline Ln TA & $\begin{array}{c}-0.0041 \text { *** } \\
(-3.07)\end{array}$ & $\begin{array}{c}-0.0037 * * \\
(-2.21)\end{array}$ & $\begin{array}{c}-0.0055 * * \\
(-2.42)\end{array}$ \\
\hline LEVERAGE & $\begin{array}{c}-0.0001 \\
(-1.43)\end{array}$ & $\begin{array}{c}-0.0001 \\
(-1.22)\end{array}$ & $\begin{array}{c}-0.0002 \\
(-1.47)\end{array}$ \\
\hline FIXED ASSETS RATIO & $\begin{array}{c}0.0009 \\
(0.23)\end{array}$ & $\begin{array}{c}0.0003 \\
(0.13)\end{array}$ & $\begin{array}{c}-0.0005 \\
(-0.05)\end{array}$ \\
\hline Ln FIRM AGE & $\begin{array}{l}0.0000 \\
(-0.11)\end{array}$ & $\begin{array}{c}-0.0011 \\
(-0.49)\end{array}$ & $\begin{array}{c}-0.0003 \\
(-0.08)\end{array}$ \\
\hline BHAR & $\begin{array}{c}-0.0065 \\
(-1.25)\end{array}$ & $\begin{array}{c}-0.0060 \\
(-1.23)\end{array}$ & $\begin{array}{c}-0.0127 \\
(-1.56)\end{array}$ \\
\hline UK LENDER & $\begin{array}{l}0.0008 \\
(-0.07)\end{array}$ & & \\
\hline UK LENDER * CRISIS & $\begin{array}{c}-0.0076 \\
(-0.80)\end{array}$ & & \\
\hline LENDER BAIL OUT & & $\begin{array}{c}-0.0149 * * * \\
(-3.30)\end{array}$ & \\
\hline LENDER BAIL OUT $*$ CRISIS & & $\begin{array}{c}0.0306 * * * \\
(3.25)\end{array}$ & \\
\hline LENDER CREDIT RATING & & & $\begin{array}{c}0.0053 \\
(0.68)\end{array}$ \\
\hline LENDER CREDIT RATING * CRISIS & & & $\begin{array}{r}-0.0072 \\
(-0.54)\end{array}$ \\
\hline Number of observations & 655 & 655 & 464 \\
\hline R-squared & 0.06 & 0.03 & 0.03 \\
\hline F-statistic & 1.91 & $2.35 * *$ & 1.77 \\
\hline
\end{tabular}

The table reports OLS regressions of abnormal returns surrounding loan announcements. The dependent variable is the three-day market model abnormal return centred on the announcement day, zero. The sample and all variables are defined in Table 1. T-statistics for standard errors clustered by issuing firm are reported in parenthesis. ${ }^{* * *}$ and ${ }^{* *}$ denote statistical significance at the $1 \%$ and $5 \%$ level respectively. 
Table 11

Difference in abnormal returns surrounding the financial crisis across borrowing source.

\begin{tabular}{|c|c|c|c|c|c|c|c|c|}
\hline & Pre-crisis & Crisis & Pre-crisis & Crisis & Pre-crisis & Crisis & Pre-crisis & Crisis \\
\hline & $(1)$ & $(2)$ & (3) & $(4)$ & $(5)$ & $(6)$ & $(7)$ & $(8)$ \\
\hline Intercept & $\begin{array}{l}0.1047 * * * \\
\quad(3.35)\end{array}$ & $\begin{array}{c}0.0411 \\
(1.20)\end{array}$ & $\begin{array}{l}0.1081 * * * \\
\quad(3.46)\end{array}$ & $\begin{array}{c}0.0369 \\
(1.06)\end{array}$ & $\begin{array}{l}0.0954 * * * \\
\quad(3.12)\end{array}$ & $\begin{array}{c}0.0390 \\
(1.15)\end{array}$ & $\begin{array}{l}0.0971 * * * \\
(3.19)\end{array}$ & $\begin{array}{c}0.0370 \\
(1.09)\end{array}$ \\
\hline BOND & $\begin{array}{c}-0.0022 \\
(-0.71)\end{array}$ & $\begin{array}{c}0.0039 \\
(0.53)\end{array}$ & $\begin{array}{c}-0.0039 \\
(-1.25)\end{array}$ & $\begin{array}{c}0.0060 \\
(0.78)\end{array}$ & & & & \\
\hline $\begin{array}{l}\text { PRIVATE } \\
\text { PLACEMENT }\end{array}$ & $\begin{array}{c}-0.0079 * * \\
(-1.97)\end{array}$ & $\begin{array}{c}-0.0020 \\
(-0.44)\end{array}$ & $\begin{array}{c}-0.0096 * * \\
(-2.34)\end{array}$ & $\begin{array}{c}0.0002 \\
(0.04)\end{array}$ & & & & \\
\hline BANK & & & & & $\begin{array}{c}0.0042 \\
(1.50)\end{array}$ & $\begin{array}{c}-0.0012 \\
(-0.23)\end{array}$ & & \\
\hline BILAT & & & $\begin{array}{c}-0.0144 * * \\
(-2.55)\end{array}$ & $\begin{array}{l}0.0075 \\
(0.98)\end{array}$ & & & $\begin{array}{c}-0.0085 \\
(-1.52)\end{array}$ & $\begin{array}{l}0.0042 \\
(0.55)\end{array}$ \\
\hline SYND & & & & & & & $\begin{array}{c}0.0059^{* *} \\
(2.03)\end{array}$ & $\begin{array}{c}-0.0034 \\
(-0.61)\end{array}$ \\
\hline Ln TA & $\begin{array}{c}-0.0046 * * * \\
(-3.48)\end{array}$ & $\begin{array}{c}-0.0020 \\
(-1.53)\end{array}$ & $\begin{array}{c}-0.0047 * * * \\
(-3.54)\end{array}$ & $\begin{array}{c}-0.0019 \\
(-1.45)\end{array}$ & $\begin{array}{c}-0.0044 * * * \\
(-3.42)\end{array}$ & $\begin{array}{c}-0.0019 \\
(-1.46)\end{array}$ & $\begin{array}{c}-0.0044 * * * \\
(-3.47)\end{array}$ & $\begin{array}{c}-0.0018 \\
(-1.38)\end{array}$ \\
\hline LEVERAGE & $\begin{array}{r}0.0045 \\
(0.82)\end{array}$ & $\begin{array}{c}-0.0000 \\
(-0.77)\end{array}$ & $\begin{array}{c}0.0043 \\
(0.79)\end{array}$ & $\begin{array}{c}-0.0000 \\
(-0.71)\end{array}$ & $\begin{array}{r}0.0047 \\
(0.87)\end{array}$ & $\begin{array}{l}-0.0000 \\
(-0.72)\end{array}$ & $\begin{array}{c}0.0045 \\
(0.84)\end{array}$ & $\begin{array}{c}-0.0000 \\
(-0.65)\end{array}$ \\
\hline $\begin{array}{l}\text { FIXED ASSETS } \\
\text { RATIO }\end{array}$ & $\begin{array}{c}0.0026 \\
(0.47)\end{array}$ & $\begin{array}{c}-0.0018 \\
(-0.16)\end{array}$ & $\begin{array}{l}0.0029 \\
(0.53)\end{array}$ & $\begin{array}{c}-0.0014 \\
(-0.13)\end{array}$ & $\begin{array}{c}0.0032 \\
(0.58)\end{array}$ & $\begin{array}{c}-0.0010 \\
(-0.09)\end{array}$ & $\begin{array}{c}0.0035 \\
(0.64)\end{array}$ & $\begin{array}{c}-0.0006 \\
(-0.06)\end{array}$ \\
\hline Ln FIRM AGE & $\begin{array}{c}0.0002 \\
(0.14)\end{array}$ & $\begin{array}{c}0.0006 \\
(0.15)\end{array}$ & $\begin{array}{c}-0.0001 \\
(-0.10)\end{array}$ & $\begin{array}{l}0.0005 \\
(0.13)\end{array}$ & $\begin{array}{c}0.0001 \\
(0.07)\end{array}$ & $\begin{array}{l}0.0005 \\
(0.14)\end{array}$ & $\begin{array}{c}-0.0002 \\
(-0.17)\end{array}$ & $\begin{array}{c}0.0004 \\
(0.11)\end{array}$ \\
\hline BHAR & $\begin{array}{l}-0.0056 \\
(-1.22)\end{array}$ & $\begin{array}{c}-0.0012 \\
(-0.21)\end{array}$ & $\begin{array}{c}-0.0052 \\
(-1.13)\end{array}$ & $\begin{array}{c}-0.0010 \\
(-0.17)\end{array}$ & $\begin{array}{l}-0.0055 \\
(-1.21)\end{array}$ & $\begin{array}{c}-0.0012 \\
(-0.21)\end{array}$ & $\begin{array}{l}-0.0052 \\
(-1.12)\end{array}$ & $\begin{array}{c}-0.0010 \\
(-0.17)\end{array}$ \\
\hline Number of observations & 835 & 561 & 835 & 561 & 835 & 561 & 835 & 561 \\
\hline R-squared & 0.0300 & 0.0026 & 0.0360 & 0.0043 & 0.0285 & 0.0022 & 0.0346 & 0.0039 \\
\hline F-statistic & $2.81 * * *$ & 0.45 & $2.95 * * *$ & 0.51 & $3.33 * * *$ & 0.41 & $3.41 * * *$ & 0.50 \\
\hline
\end{tabular}

The table reports OLS regressions of abnormal returns surrounding loan announcements. The dependent variable is the three-day market model abnormal return centred on the announcement day, zero. BOND is a dummy variable set equal to one where the borrowing source is a public bond issue, and zero otherwise. PRIVATE PLACEMENT is a dummy variable set equal to one where the borrowing source is a private, non-bank lender. BANK is a dummy variable set equal to one where the borrowing source is a bank entity, and zero otherwise. SYND is a dummy variable set equal to one where the borrowing source is a multi-lender bank loan, and zero otherwise. BILAT is a dummy variable set equal to one where the borrowing source is a single lender bank loan. The sample and all remaining variables are defined in Table 1 . T-statistics for standard errors clustered by issuing firm are reported in parenthesis. ${ }^{* * *}$ and ${ }^{* *}$ denote statistical significance at the $1 \%$ and $5 \%$ level respectively. 
Table 12

Abnormal returns surrounding debt announcements across various event windows.

\begin{tabular}{lccccc}
\hline & Public Bonds & Bank Loans & $\begin{array}{c}\text { Syndicated } \\
\text { Loans }\end{array}$ & $\begin{array}{c}\text { Bilateral } \\
\text { Loans }\end{array}$ & Privately Placed Debt \\
\hline Market model returns & $0.19 \%$ & $0.63 \%$ & $0.65 \%$ & $0.55 \%$ & $-0.07 \%$ \\
CAAR $(-1,0)$ & $(1.04)$ & $(3.36)^{* * *}$ & $(3.13)^{* * *}$ & $(1.28)$ & $(-0.31)$ \\
& {$[0.84]$} & {$[3.08]^{* * *}$} & {$[2.53]^{* *}$} & {$[1.85]$} & {$[-0.77]$} \\
CAAR $(-2,0)$ & $0.04 \%$ & $0.64 \%$ & $0.75 \%$ & $0.18 \%$ & $-0.33 \%$ \\
& $(0.18)$ & $(2.93)^{* * *}$ & $(3.31)^{* * *}$ & $(0.30)$ & $(-0.83)$ \\
Market-adjusted model returns & {$[0.24]$} & {$[2.70]^{* * *}$} & {$[2.67]^{* * *}$} & {$[0.62]$} & {$[-1.18]$} \\
CAAR $(-1,0)$ & $0.24 \%$ & $0.64 \%$ & $0.69 \%$ & $0.47 \%$ & $0.01 \%$ \\
& $(1.23)$ & $(3.46)^{* * *}$ & $(3.33)^{* * *}$ & $(1.10)$ & $(0.05)$ \\
CAAR (-2, 0) & {$[1.63]$} & {$[3.58]^{* * *}$} & {$[2.91]^{* * *}$} & {$[2.10]^{* *}$} & {$[-0.70]$} \\
& $0.11 \%$ & $0.67 \%$ & $0.81 \%$ & $0.09 \%$ & $-0.27 \%$ \\
& $(0.54)$ & $(3.11)^{* * *}$ & $(3.63)^{* * *}$ & $(0.16)$ & $(-0.67)$ \\
Number of observations & {$[0.90]$} & {$[3.52]^{* * *}$} & {$[3.12 * * *]$} & {$[1.44]$} & {$[-1.06]$} \\
\hline
\end{tabular}

The table reports three-day cumulative average abnormal returns (CAARs) centred on the announcement day, zero for a sample of debt announcements. Market model and market-adjusted model returns are estimated using a 170-day estimation window beginning on day -200 relative to the event day. The FTSE 350 index is used as the market benchmark for estimating CARs. The sample and all variables are defined in Table $1 .{ }^{* * *}$ and ${ }^{* * *}$ denote statistical significance at the $1 \%$ and 5\% level respectively. T-statistics are reported in parentheses and Kolari and Pynnönen (2010) corrected t-tests are presented in brackets. 